\title{
International Migration and Health in the Countries of Origin. The Effect on Households with Migrants and/or Recipients of Remittances, and on Returned Migrants. A Systematic Review*
}

\section{La migración internacional y la salud en los países de origen. El efecto sobre los hogares por los migrantes y/o receptores de las remesas y sobre los migrantes retornados. Una revisión sistemática}

\section{A migração internacional e a saúde nos países de origem. Efeito nas famílias pelos migrantes e/ou destinatários das remessas e nos migrantes devolvidos. Uma revisão sistemática}

Date received: 20 March 2018. Date accepted:

16 May 2019. Date published: 29 November 2019.

DOI: https://doi.org/10.11144/Javeriana.rgps18-37.imhc

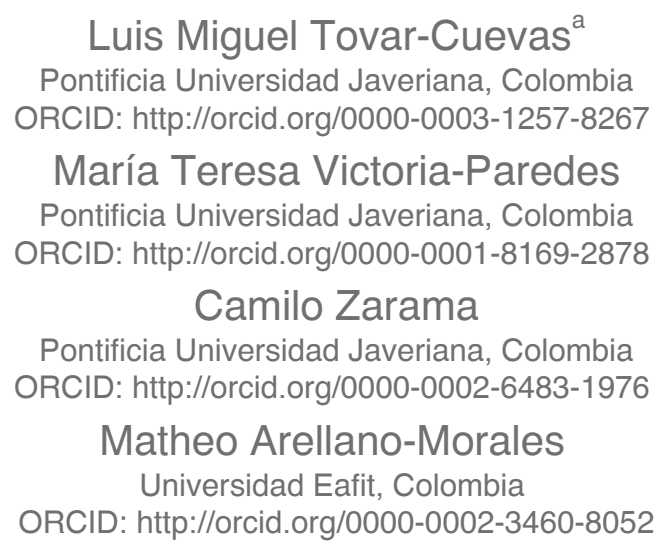

How to cite this article:Tovar-Cuevas LM, Victoria-Paredes MT, Zarama C, Arellano-Morales M. International migration and health in the countries of origin. The effect on households with migrants and/or recipients of remittances, and on returned migrants. A systematic review. Revista Gerencia y Políticas de Salud. 2019;18(37). https://doi.org/10.11144/Javeriana.rgps18-37.imhc

${ }^{a}$ Corresponding author. E-mail: luismtovar@gmail.com 


\section{Abstract}

This work represents a systematic literature review that studies the effect of international migration on the health of households in the countries of origin and of returned migrants. The effect is due to: 1) remittances, 2) transfer of ideas, habits and behavioral norms, and 3) the previous migratory experience of returned migrants. Aspects of health that may be affected are fertility rate, general health condition, access to health services, mental health, life expectancy, anthropometric measures and nutrition, health expenditure, risk factors or health protectors. The search included articles and documents published between January 2000 and August 2017, written in English or Spanish, included in the databases Jstor, Proquest, IDEAS-RePec, Scielo, Google Scholar and PubMed. Based on quantitative and qualitative methodologies, the 85 selected articles, found positive and/or negative effects on health of children, adolescents, women, older adults and returned migrants. This systematic review offers a broad look of the effects of international migration on the health of the ones who stay, which results useful for policy makers and researchers. Not all findings are consistent and therefore, further research on the matter is necessary, considering qualitative approaches.

Keywords: emigration, return, immigration, mental health, child health, adult health, health status, health services accessibility, risk factors.

\section{Resumen}

Este trabajo representa una reseña sistemática de la literatura que estudia el efecto de la migración internacional sobre la salud de los hogares en los países de origen y en los migrantes retornados. El efecto se debe a: 1) las remesas, 2) la transferencia de ideas, hábitos y normas de conducta, y 3 ) la experiencia migratoria previa de los migrantes retornados. Aspectos de la salud que pueden verse afectados son la tasa de fertilidad, la condición general de salud, el acceso a los servicios de salud, la salud mental, la expectativa de vida, las medidas antropométricas y la nutrición, los gastos en salud, los factores de riesgo o los factores de protección de la salud. La búsqueda incluyó artículos y documentos publicados entre enero de 2000 y agosto de 2017, escritos en inglés o español, incluidos en las bases de datos Jstor, Proquest, IDEAS-RePec, Scielo, Google Scholar y PubMed. Con base en metodologías cuantitativas y cualitativas, los 85 artículos seleccionados encontraron efectos positivos y/o negativos sobre la salud de los niños, adolescentes, mujeres, adultos mayores y migrantes retornados. Esta revisión sistemática ofrece una amplia mirada a los efectos de la migración internacional sobre la salud de quienes se quedan, cosa que resulta útil para quienes crean las políticas y para los investigadores. No todos los hallazgos son consistentes y, por consiguiente, se necesita más investigación sobre el asunto considerando los enfoques cualitativos.

Palabras clave: emigración, retorno, inmigración, salud mental, salud infantil, salud del adulto, condición de salud, accesibilidad a los servicios de salud, factores de riesgo.

\section{Resumo}

Este trabalho apresenta resenha sistemática da literatura que estuda o efeito da migração internacional na saúde das famílias nos países de origem e nos migrantes devolvidos. O efeito é devido a: 1) as remessas, 2) a transferência de ideias, hábitos e regras de conduta, e 3) a experiência migratória anterior dos migrantes que retornam. Aspectos da saúde que podem ser afeitados são taxa de fertilidade, estado geral de saúde, acesso a serviços de saúde, saúde mental, expectativa de vida, medidas antropométricas e nutrição, despesas em saúde, fatores de risco ou fatores de proteção à saúde. A busca incluiu artigos e documentos publicados entre janeiro de 2000 e agosto de 2017, escritos em inglês ou espanhol, incluídos nas bases de dados Jstor, Proquest, IDEAS-RePec, Scielo, Google Scholar e PubMed. Baseados em metodologias quantitativas e qualitativas, os 85 artigos escolhidos encontraram efeitos positivos e/ou negativos sobre a saúde das crianças, adolescentes, mulheres, idosos e migrantes retornados. Esta revisão sistemática oferece uma visão ampla dos efeitos da migração internacional sobre a saúde daqueles que ficam, o que resulta útil para formuladores de políticas e pesquisadores. Nem todos os achados são consistentes e, portanto, mais pesquisa sobre o assunto considerando abordagens qualitativos é precisa.

Palavras-chave: emigração, retorno, imigração, saúde mental, saúde infantil, saúde do adulto, estado de saúde, acessibilidade a serviços de saúde, fatores de risco. 


\section{Introduction}

According to The World Bank (1), as a result of globalization, political conflicts, climate change and, social and economic problems that afflict countries, international migration has increased around the world. In 2013, more than 247 million people were living in different countries from that in which they were born, and the flows of world remittances increased to US $\$ 583,000$ million in 2014.

International migration (emigration, immigration, return, remittances) may affect the health of emigrants, indigenous population of the receiving countries, members of the household that stay in the countries of origin and performance of health systems. Available literature on the effect of international migration on health is abundant and it is mainly focused on the effects that it produces on the health of immigrants and on the impact that the drain of health professionals has on health systems. However, the interest for studying the impact of migration on health has increased in the countries of origin, since developing countries are those which produce most emigrants and the health of population, as well as the possibility that the former has to access to health services, constitute key elements to achieve economic development (2).

There is evidence that international migration may affect the health of all the members in the household that stay in the countries of origin. For instance, it can negatively affect the health of children since they receive less preventive health care (3) or it constitutes a stressful situation that affects psychological wellbeing $(4,5,6)$. It could also present positive effects such as the increase of the expenditure and demand of health services as a result of the reception of remittances $(7,8,9)$, the improvement of child nutrition indicators $(10,11)$ and the decrease of child mortality (12).

International migration affects the health of adolescents and youngsters when enabling the acquisition of unhealthy habits such as smoking (13) and producing emotional stress (14). Mental health of women may also be affected $(15,16,17)$, as well as the diet of older adults (18). On the other hand, emigrants and returned migrants, can also transfer values, norms and practices acquired abroad for the benefit of their communities that may affect health outcomes $(19,20)$.

Several are the ways through which migration (emigration, return, remittances) affects health outcomes in the countries of origin, diverse are the health outcomes that may be affected and the effects can be positive, negative or appear in both directions. In spite of the fact that migration effects on people that stay in the countries of origin are multidimensional, studies generally focus on only one part of them, making it difficult to understand its true impact. For instance, when a study focuses on anthropometric measures, it can put to one side the psychological aspects that could simultaneously be affected.

The study of the effects of international migration on health outcomes of people and households in the countries of origin is a less-paid attention subject in comparison to the studies focused on 
the destination countries. Therefore, this systematic review pretends to contribute with a broad panorama of the different ways in which international migration may affect health outcomes in the countries of origin. This effect can take place due to: 1) families may receive remittances, or have a family member who has returned or is living abroad; and 2) the health of returned migrants may have been affected by the previous migratory experience.

In this sense, this systematic review is addressed by the following question: which are the effects that international migration, seen from remittances, return or emigration, produce on the health condition of people or households in the countries of origin?

\section{Methods}

The systematic review was carried out in two phases. In the first, which did not include the PubMed database and concluded on March $16^{\text {th }}, 2016$, published articles between January $1^{\text {st }}$, 2000 and January $1^{\text {st }}, 2016$ were searched. In the second phase, which concluded on August $21^{\text {st }}, 2017$, published articles between January $1^{\text {st }}, 2000$ and August $15^{\text {th }}, 2017$ were searched in the PubMed database and published articles between January $1^{\text {st }}, 2016$ and August $15^{\text {th }}, 2017$ were searched in the other databases.

The following descriptors in English and Spanish were used for the search: health (salud), mortality (mortalidad), morbidity (morbilidad), disease (enfermedad), mental health (salud mental), mental illness (enfermedad mental), nutrition (nutrición), child health (salud infantil), infant mortality (mortalidad infantil), health expenditure (gasto en salud), remittances (remesas), international migration (migración internacional), emigration (emigración) and return migration (migración de retorno). The last four descriptors were combined with each of the considered possible health outcomes. Each database was reviewed independently by two authors and results of the search were compiled using Mendeley. It is worth mentioning the fact that the search is limited to published articles only in Spanish or English may be a potential source of bias, since it excludes published articles in other languages.

Data from Ebsco, Jstor, Proquest, Pubmed, IDEAS RePec, Scielo and Google Schoolar were taken into account for the review of articles. The Boolean connector "and" was used in all cases. Keywords were combined with the conjunction "and" in the databases which do not have the option to choose the Boolean connector (IDEAS RePec, Scielo and Google Scholar).

Original articles, published in scientific journals and working papers that represented empirical, quantitative or qualitative works were included. Thesis, editorials, articles based on opinion or reflection, systematic reviews, book chapters or texts presented in academic events were established as exclusion criteria. The articles that marginally referred to the subject were also excluded; those that focused on internal migration or did not differentiate between internal or 
international migration and the articles that treat health condition as a determining factor of migration or focus on the effects on the countries of destination were also excluded.

The search strategy showed 471 academic articles and working papers: Ebsco (91), Jstor (27), Proquest (109), IDEAS RePec (59), Scielo (49), Google Schoolar (95) and Pubmed (41) (this figure includes duplicates). After the review process, 85 articles remained. Figure 1 describes in detail the process of the systematic review

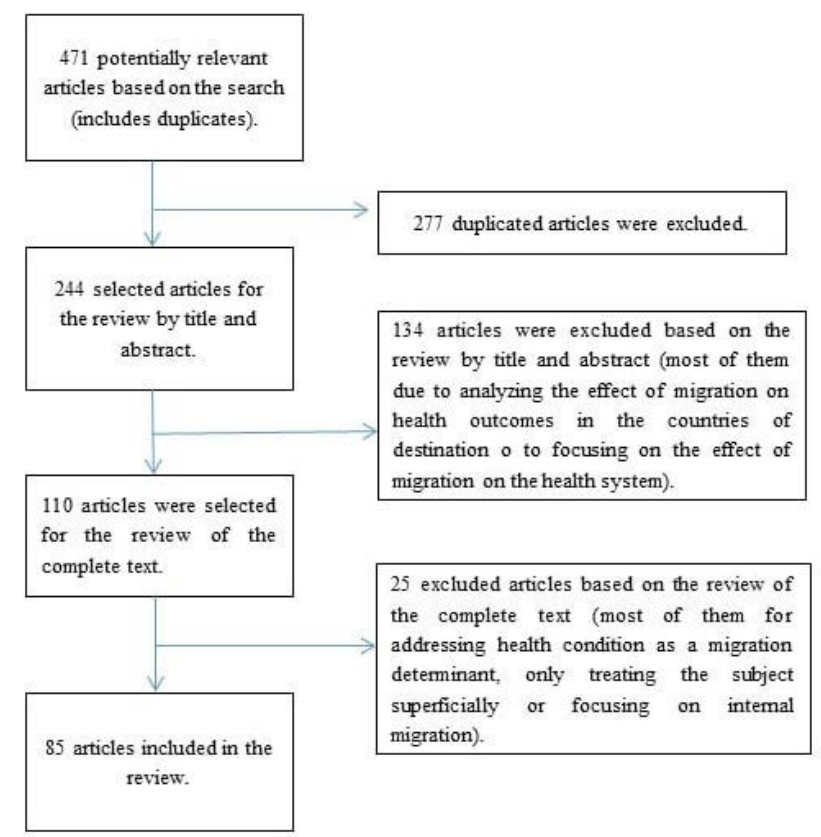

Figure 1. Process of systematic review

Source: own work

For purposes of analysis, the information extracted from the studies was: author(s), year of publication, target population, sample size, city and country, objective, type of study, recollection technique and data analysis, main results and conclusions. These data were systematized in a table of evidence that would allow its subsequent categorization and analysis. From this systematization, three categories under which the works could be classified were: 1) the effect of emigration or the return of a family member on the health of the members of the households in the country of origin (36 articles), 2) the effect of transfers, monetary and nonmonetary (ideas) on health or health expenditure of households in the countries of origin (27 articles), 3) the effect of the migratory experience on the health condition of those who returned ( 8 articles). Some articles analyzed two of these categories at the same time (14 articles).

\section{Results}

The systematic review produced 85 articles, from which 73 were published in scientific journals that received peer evaluation and the others were working papers on economics. No published studies that complied with the inclusion criteria were found in 2000 and $2001.81 .2 \%$ of the studies were published between 2009 and 2017. Most articles (88.2\%) were published in English. The country in which the selected studies focused the most was Mexico (38 articles). 
Table 1 shows the total of documents by country in each region. Most of the studies found in Mexico can be due to its broad migratory tradition and to limiting the search to two languages.

Table 1. Number of studies by region and country

\begin{tabular}{|c|c|c|c|c|c|c|c|c|c|c|c|}
\hline \multicolumn{3}{|c|}{ Asia } & \multicolumn{3}{|c|}{$\begin{array}{l}\text { Latin America and The } \\
\text { Caribbean }\end{array}$} & \multicolumn{3}{|c|}{ Sub-Saharan Africa } & \multicolumn{3}{|c|}{ Europe } \\
\hline Country & Freq & $\%$ & Country & Freq & $\%$ & Country & Freq & $\%$ & Country & Freq & $\%$ \\
\hline China & 1 & 8.3 & Brazil & 1 & 1.8 & Sub-Saharan & 1 & 14.3 & Albany & 1 & 20 \\
\hline Philippines & 1 & 8.3 & Colombia & 2 & 3.8 & Ghana & 1 & 14.3 & Ireland & 2 & 40 \\
\hline India & 1 & 8.3 & Ecuador & 3 & 5.7 & Malawi & 1 & 14.3 & Moldava & 2 & 40 \\
\hline Kyrgyzstan & 1 & 8.3 & Guatemala & 4 & 7.5 & Mozambique & 1 & 18.2 & Total region & 5 & 100 \\
\hline Sri Lanka & 4 & 33.2 & Jamaica & 1 & 1.8 & Nigeria & 1 & 14.3 & Oceania & & \\
\hline Thailand & 1 & 8.3 & Mexico & 38 & 71.7 & Ethiopia & 1 & 14.3 & Country & Freq & $\%$ \\
\hline Tajikistan & 1 & 8.3 & $\begin{array}{l}\text { Several } \\
\text { countries }\end{array}$ & 2 & 3.8 & $\begin{array}{l}\text { Ghana, } \\
\text { Nigeria and } \\
\text { Angola }\end{array}$ & 1 & 14.3 & Tonga & 2 & 100 \\
\hline Vietnam & 1 & 8.3 & $\begin{array}{l}\text { Guadeloupe } \\
\text { and } \\
\text { Martinique }\end{array}$ & 1 & 1.8 & & & & Several region & & \\
\hline $\begin{array}{l}\text { Indonesia, } \\
\text { Philippines } \\
\text { and } \\
\text { Vietnam }\end{array}$ & 1 & 8.3 & Honduras & 1 & 1.8 & & & & Country & Freq & $\%$ \\
\hline $\begin{array}{l}\text { Total } \\
\text { region }\end{array}$ & 12 & 100 & Total region & 53 & 100 & Total region & 7 & 100 & $\begin{array}{l}\text { Developing } \\
\text { countries }\end{array}$ & 6 & 100 \\
\hline
\end{tabular}

* Bolivia, Ecuador, El Salvador, Guatemala, Haiti, Honduras, Mexico, Nicaragua, Paraguay, Peru and Dominican Republic. Source: own work, based on reviewed literature

In general terms, the target populations of the reviewed articles were: 1) children, 2) adolescents, 3 ) women, 4) older adults and 5) households. Seventy-eight quantitative articles, 4 qualitative articles $(21,22,23,24)$ and three mixed were found $(4,25,26)$. Seventy three percent of the works reviewed corresponded to cross-sectional studies (sixty-two articles). Of these, thirtysix articles, were comparative, of which three were descriptive, and one related to cases and controls. $22 \%$ of the studies were longitudinal (nineteen articles), the majority of these being comparative (twelve articles). Of the work with a qualitative approach, ethnographic designs (four articles) and narrative (two articles) predominated. The type of study, target population and sample size of each of the reviewed studies are described in annex 1. Approximately, $43.5 \%$ of the studies reported the presence of selection bias due to un-observed variables and inverse causality, which can cause endogeneity problems, which, if untreated, may produce biased estimations of the impact of migration on health outcomes. This problem was more common in the studies that analyzed the effect of remittances on health expenditure or some health-related outcomes. The strategies most used to avoid biased estimations were the instrumental variables $(12,27,28,29,30,31,32,33,34)$, estimation through the methods Propensity Score Matching and the models of difference in differences $(35,36)$, as well as the use of estimators of fixed effects, in the case of the models with panel data $(37,38,39)$. 
Figure 2 shows the different health outcomes that, in the countries of origin are affected by international migration, according to the reviewed literature.



Figure 2. Health outcomes affected by international migration in the countries of origin Source: own work, based on reviewed literature

\section{Effect of emigraton or return of a family member on health conditions of the household in the origin countries}

The fact of having a migrant or a returnee brings about changes in the household that can have an influence on health outcomes. These changes have to do with the responsabilities taken on by the members of the household, gender-related roles, and the supply of care, support and supervision.

According to Banerjee et al. (40), women, for instance, can be forced to take on new responsibilities, with which the fertility rate can be affected and prenatal and postnatal care can decrease, having an influence on variables such as early death of their children in migrant households. Contrary to Lindstrom and Muñoz-Franco (41), women who have migrant relatives have a greater probability of receiving prenatal and postnatal care and assistance at birth, due to the decrease of financial and cultural barriers, by means of remittances and the diffusion of new ideas, attitudes and behaviors.

Jayatissa and Wickramage (42) support the idea that migration decreases childcare because of the time limitations of the father, and Schmeer (43) that it can explain the lack of support and supervision that children require, contributing to the generation of diseases or diarrhea. 
Naturally, if the mother, in the country of origin, has greater autonomy and resources, the effect can be positive. Likewise, the lack of supervision that migrants can carry out on their children, could be associated with the use and abuse of substances such as alcohol, marihuana and cocaine by the migrants' relatives in Mexico (44).

Additionally, the support that migrant children cannot give to older parents can be associated with the fact that these suffer from a mental illness or have experienced a heart attack or a cardiovascular accident (45). Barrett and Mosca (46) found that especially older mothers of migrant children were depressed and felt lonely.

On the other hand, international migration can create stress among the family members who stay. According to Pottinger (5), migration of parents represents a potential trauma for the children that stay, placing them in a situation of higher risk regarding psychosocial problems. Smeekens et al. (14), obtained similar results when concluding that adolescents missed their parents very much and felt lonely and stressed, which affected their physical condition; and Ming-Hsuan (13), for whom children with migrant parents had less chances of being vaccinated and were more likely to smoke, can be associated with a deficient family relationship or a weak connection with their parents in their youth.

Rivera-Heredia et al. (25) studied the perception of daughters, mothers, wives or sisters of migrants on the stressful events associated with international migration (absence of partner, uncertainty and concern for the migrant, lack of money and children's health). They found that women can experience loneliness, sadness and anger, as well as fatigue, insomnia and depression. To similar conclusions reached Siriwardhana (23) in a study for Sri Lanka about the migrants spouses.

Additionally, international migration affects the social networks of support with which the families of migrants rely on. However, according to Frank (17), even though women with migrant spouses dealt with greater stress and less support during pregnancy, the probability of low weight at birth did not increase and birth results were positive. This might be due to better conduct practices of women; naturally, excluding those whom are less willing to exclusively breastfeed their babies. In the same way, Azzarri and Zezza (10) suggest that migration has a negative impact on the duration of exclusive breastfeeding, if their job imposes additional restrictions of time to breastfeeding mothers, and these know and can access breast milk substitutes more easily.

Table 2 summarizes the main results of the articles that deal with the effect of emigration or the return of a family member on health in the countries of origin. Some studies found positive effects; others, negative ones. With regard to child mortality, all the articles found positive effects $(3,47,48,49)$. The opposite occurred with risk factors, the migration of a family member increases the probability that children and/or adolescents smoke (13), consume more alcohol 
or psychoactive substances (4) and exercise less (50). It also affects alcohol consumption of older adults (44,51). Child care practices decrease (42) and the contagion risk of HIV/ITS increases (22). On the other hand, the migration of a family member decreases the incidence of pregnancy in adolescents (52).

Negative effects were found in different indicators of mental health in children $(5,53,54)$, adolescents $(4,6,55)$, caregivers $(26,23)$, older adults $(45,56)$, wives of the migrants $(15,16,25,57)$, spouses $(23)$ and members of the household in general (58).

Migration also has positive effects on the access to private health services (59), healing (60), and of antenatal control (61), as well on the use of contraceptive methods (41). In contrast, the migration of a family member family can negatively affect vaccinations of children $(3,13)$ and the search of medical care of grandparents (23).

With respect to the indicators that describe the general health conditon, results are ambiguous. While some studies found that the migration of the parents or a family member was associated with a better self-reported health condition (18) and the decrease of the Body Mass Index and blood pressure (51), other unfavorable results such as the increase of the probability that children younger than 5 years suffer from a disease due to the absence of their parents $(9,43)$, the deterioration of physical health of adolescents (14), the decrease in the propensity to selfreport good health $(45,51)$, the increase of the report of heart diseases $(15)$.

Results in terms of the effects on the anthropometric measures and nutritional condition are not convincing either. There is evidence of positive impacts on the children's nutritional condition $(10,40)$, the diet of older adults $(18)$, the increase of weight at birth $(3,19)$, the weight conditions of children younger than 15 years old (9) and the decrease in the prevelance of growth retardation $(62,42)$. However, some studies reported negative effects such as the worsening of the diet of the household members $(51,63)$, malnutrition among pre-schoolers (64), children younger than 18 years old would present growth retardation $(63,65)$, the migrants' wives (15), and children between 1 and 5 years old were overweight (64), a part from the abandonment of exclusive breastfeeding (10).

In the countries of origin, the health of families may be affected by the return of any of their members. In fact, according to Cárdenas et al. (35), in Colombia, the migratory experience has a positive influence on the total health expenditure per month; mainly due to the effect on households with returned migrants.

However, several studies carried out for Mexico reached to similar conclusions. Hamilton and Choi (11) found that return migration was associated to a lower risk of low birth weight and to a higher risk of macrosomy. To Flores et al. (49), in the Mexican states, an increase of 10\% in the households with returned migrants may be associated to a decrease of $5.5 \%$ in child mortality rates; which may be related to the exposition to practices that produced better child health results in the United States $(66,67,68)$. 
Donato and Duncan (68) studied children's health in three types of Mexican families: 1) those who lived in the United States, 2) those who had returned from the United States, and 3) those who lived in Mexico and had never had a migratory experience. They found that children's health was better in the families who lived in the United States, and significantly worse when they lived in returned families. A possible explanation to this was the called 'salmon effect', according to which, the ones who returned were the least healthy and successful.

Finally, Hernández-Rosete et al. (22) found that indigenous women of the Mexican rural zone were in risk of contracting AIDS, since they felt they were forced into having un-protected sex when their husbands returned from the United States; despite the fear that they were infected with the virus, as a result of having being unfaithful. Additionally, men were seeking to get them pregnant and control them. Other authors did not find evidence that migration or the return of a family member affected health-related outcomes, such as mental health of children $(5,53)$ and older adults, (18), suicidal risk (66), the health perception of people (35), child mortality (67), the probability of low weight at birth (17), or malnutrition (64). Ullmann (15) does not find that having a migrant husband compared to not having one produces significant differences in hypertension, diabetes or having smoked once.

Table 2. Main effects of emigration or return of a family member on health outcomes in the countries of origin

\begin{tabular}{|c|c|c|}
\hline Author & Effect on health & Country \\
\hline \multicolumn{3}{|c|}{ Access to or use of health services } \\
\hline $\begin{array}{l}\text { Salgado de Snyder et al. } \\
\text { (59) }\end{array}$ & The use of private health services was greater in migrant households. & Mexico \\
\hline Siriwardhana et al. (23) & $\begin{array}{l}\text { Taking care of grandsons when the father migrates prevents grandparents from } \\
\text { seeking medical care for their health problems, which aggravates the feeling of } \\
\text { poor health. }\end{array}$ & Sri Lanka \\
\hline $\begin{array}{l}\text { Lopez-Cevallos and Chi } \\
(60)\end{array}$ & $\begin{array}{l}\text { Having a migrant relative increased the use of anti-parasitic medication and of } \\
\text { curative care consultations in the low-income households. }\end{array}$ & Ecuador \\
\hline $\begin{array}{l}\text { Lindstrom and Muñoz- } \\
\text { Franco }(61)\end{array}$ & $\begin{array}{l}\text { Women of rural areas with migrant relatives are } 1.7 \text { times more likely to use } \\
\text { formal prenatal care that those women without a migrant relative. Migration } \\
\text { also favors the access to assisted labor. }\end{array}$ & Guatemala \\
\hline Banerjee et al. (40) & $\begin{array}{l}\text { In migrant households, } 5 \% \text { of mothers with basic education have informed not } \\
\text { receiving any prenatal care in comparison to } 1 \% \text { in the case of non-migrant } \\
\text { households. }\end{array}$ & India \\
\hline $\begin{array}{l}\text { Lindstrom and Muñoz- } \\
\text { Franco (41) }\end{array}$ & $\begin{array}{l}77.4 \% \text { of women who have a migrant relative have knowledge of more than } 3 \\
\text { modern contraceptive methods and } 27.6 \% \text { use them. } 65.1 \% \text { of women from } \\
\text { communities where international migration is common, more than } 3 \text { modern } \\
\text { contraceptive methods are known and } 20.9 \% \text { use them. }\end{array}$ & Guatemala \\
\hline Ming-Hsuan (13) & $\begin{array}{l}\text { Children with migrant parents were less likely to receive vaccinations and on } \\
\text { average, they enjoyed of less medical care than those who did not have migrant } \\
\text { parents. }\end{array}$ & China \\
\hline Caballero et al. (21) & $\begin{array}{l}\text { When a woman is left alone due to the partner's migration, she has greater } \\
\text { freedom to decide about attending to services related to sexual and reproductive } \\
\text { health and whether to continue using contraceptive methods. }\end{array}$ & Mexico \\
\hline $\begin{array}{l}\text { Hildebrandt and } \\
\text { McKenzie (3) }\end{array}$ & $\begin{array}{l}\text { Children from migrant households have less probabilities of being breastfed, } \\
\text { vaccinated or taken to a doctor in their first year. }\end{array}$ & Mexico \\
\hline
\end{tabular}


International Migration and Health in the Countries of Origin. The Effect on Households with Migrants and/or Recipients of Remittances, and on Returned Migrants. A Systematic Review

Table 2. Main effects of emigration or return of a family member on health outcomes in the countries of origin (Continuation)

\begin{tabular}{|c|c|c|}
\hline Author & Effect on health & Country \\
\hline \multicolumn{3}{|l|}{ Mental health } \\
\hline $\begin{array}{l}\text { Aguilera-Guzmán et al. } \\
\text { (4) }\end{array}$ & $\begin{array}{l}\text { Children of migrant parents are more vulnerable to psychosocial problems } \\
\text { (scholar drop-out, drug abuse, child and family abuse) than those of non-migrant } \\
\text { parents. }\end{array}$ & Mexico \\
\hline Ullmann (15) & $\begin{array}{l}\text { Children of migrant parents are more vulnerable to psychosocial problems } \\
\text { (scholar drop-out, drug abuse, child and family abuse) than those of non-migrant } \\
\text { parents. }\end{array}$ & Mexico \\
\hline Vanore_et_al (54) & $\begin{array}{l}\text { Boys that have a migrant father have a greater probability of having conduct } \\
\text { problems, but do not have a significant influence in the scale of emotional } \\
\text { symptoms. In the case of girls, it does not affect none of the two measures. }\end{array}$ & Moldavia \\
\hline Antman (45) & $\begin{array}{l}\text { Having a child in The United States is associated with a } 3.2 \% \text { increase in the } \\
\text { probability that older parents have poor mental health. Women are the most } \\
\text { affected ones. }\end{array}$ & Mexico \\
\hline Bojorquez et al. (58) & $\begin{array}{l}\text { Having a migrant partner in The USA was associated with a greater probability } \\
\text { of suffering from depressive symptoms. }\end{array}$ & Mexico \\
\hline Siriwardhana et al. (47) & $\begin{array}{l}\text { Most of the interviewed people mentioned suffering from low moods, sadness, } \\
\text { anxiety and depressive symptoms due to the labor migration of their family } \\
\text { member. }\end{array}$ & Sri Lanka \\
\hline Pottinger (5) & $\begin{array}{l}\text { Children's unhappiness due to migration of their parents was directly related to } \\
\text { depressive symptoms and suicidal thoughts or ideas. There was not an } \\
\text { association with their behavior. }\end{array}$ & Jamaica \\
\hline Adhikari et al. (53) & $\begin{array}{l}\text { Children with migrant parents have a score of abnormal hyperactivity, compared } \\
\text { to those with non-migrant parents. The father's migration does not affect } \\
\text { mental health of children, but the mother's does affect them. }\end{array}$ & Thailand \\
\hline Borges et al. (66) & $\begin{array}{l}\text { In comparison to people without migrant background (that has not migrated or } \\
\text { has a migrant family member), the risk of suicidal ideas or suicidal attempt was } \\
\text { greater among Mexicans with family members in the USA. There were no } \\
\text { differences with returning migrants. }\end{array}$ & Mexico \\
\hline Mosca and Barrett (56) & $\begin{array}{l}\text { The emigration of a child affects negatively mental health of the mothers left } \\
\text { behind; they present greater depressive symptoms, deterioration in self- } \\
\text { perception of mental health and greater feelings of loneliness. No significant } \\
\text { effects are found related to the fathers. }\end{array}$ & Ireland \\
\hline
\end{tabular}

Souce: own work, based on reviewed literature 


\section{Table 2. Main effects of emigration or return of a family member on health outcomes in the countries of origin (Continuation)}

\begin{tabular}{|c|c|c|}
\hline Author & Effect on health & Country \\
\hline \multicolumn{3}{|l|}{ Mental health } \\
\hline Graham et al. (26) & $\begin{array}{l}\text { In Indonesia, the probability of suffering from Common Mental Disorders } \\
\text { (CMD) is two times higher in families with migrant relatives than in families } \\
\text { without migrants. Mothers that stay have a } 2.5 \text { higher probability of suffering } \\
\text { from CMD than those without a migrant husband. Likewise, mothers are more } \\
\text { likely to suffer from poor mental health in the three countries. Caregivers who } \\
\text { have little contact with migrant fathers are } 2 \text { times more likely to experience } \\
\text { CMD than those who keep in contact once on a weekly basis. }\end{array}$ & $\begin{array}{l}\text { Indonesia, } \\
\text { Philippines } \\
\text { and } \\
\text { Vietnam }\end{array}$ \\
\hline Rivera-Heredia et al. (25) & $\begin{array}{l}\text { Even though women who stay can report positive reactions (pride, hope, } \\
\text { happiness, tranquility and faith) regarding stressful events caused by the } \\
\text { migration of a family member, negative reactions predominate (sadness, } \\
\text { loneliness, anxiety, concern and insomnia). }\end{array}$ & Mexico \\
\hline Mazzucato et al. (55) & $\begin{array}{l}\text { Children from transnational families have higher levels of psychological } \\
\text { disorders than those who live with their parents. }\end{array}$ & $\begin{array}{l}\text { Ghana, } \\
\text { Nigeria, } \\
\text { Angola }\end{array}$ \\
\hline Wilkerson et al. (16) & Women with emigrant husbands tend to have a poorer mental health. & Mexico \\
\hline Nobles et al. (57) & $\begin{array}{l}\text { There is a greater probability of reporting a depressive symptom when the father } \\
\text { is at The USA. The absence of the spouse is associated with a greater probability } \\
\text { of reporting sadness, lack of sleep, crying, obsessive thoughts and loneliness. The } \\
\text { returning of the spouses decreases these symptoms. }\end{array}$ & Mexico \\
\hline Siriwardhana et al. (23) & $\begin{array}{l}\text { The incidence of } \mathrm{CMD} \text { among adults who are left behind is greater in } \\
\text { comparison to national incidence. Caregivers that are not spouses in families } \\
\text { that are left behind, presented more than twice CMD than the group of spouses. }\end{array}$ & Sri Lanka \\
\hline Wickramage et al. (6) & $\begin{array}{l}\text { The burden of emotional problems and hyperactivity is greater in children of } \\
\text { families with migrants in comparison to those of families without migrants. Two } \\
\text { out of five children left behind had clinically relevant secondary psychiatric } \\
\text { disorders. }\end{array}$ & Sri Lanka \\
\hline Frank (17) & $\begin{array}{l}\text { Women with migrant husbands reported receiving less social support during } \\
\text { pregnancy and suffer from more stress. }\end{array}$ & Mexico \\
\hline
\end{tabular}

Souce: own work, based on reviewed literature 
International Migration and Health in the Countries of Origin. The Effect on Households with Migrants and/or Recipients of Remittances, and on Returned Migrants. A Systematic Review

Table 2. Main effects of emigration or return of a family member on health outcomes in the countries of origin (Continuation)

\begin{tabular}{|c|c|c|}
\hline Author & Effect on health & Country \\
\hline \multicolumn{3}{|c|}{ Nutrition and anthropometric measures } \\
\hline Banerjee et al. (40) & $\begin{array}{l}\text { The nutritional condition of children among migrant families is comparatively } \\
\text { better than their non-migrant counterparts. }\end{array}$ & India \\
\hline Azzarri and Zezza (10) & $\begin{array}{l}\text { Living in a household with migrant relatives increases the score of size-for-age of } \\
\text { the child ( } \mathrm{z} \text {-score) in } 2 \text { standard deviations. Migration has a positive and } \\
\text { significant influence on calories consumption and can negatively affect the } \\
\text { breastfeeding period. }\end{array}$ & Tajikistan \\
\hline Gibson et al. (63) & $\begin{array}{l}\text { Migration of parents decreases the weight-for-age of the children that stay in } \\
0.63 \text { standard deviations. The effect disappears when controls are added. The } \\
\text { rates of growth retardation are higher for the children who stay than for the } \\
\text { children who migrate with their parents. }\end{array}$ & Tonga \\
\hline $\begin{array}{l}\text { Acosta and Vizcarra- } \\
\text { Bordi }(64)\end{array}$ & $\begin{array}{l}\text { The incidence of malnutrition in preschoolers in households with male } \\
\text { migration, for the size-for-age indicator is } 5.71 \% \text { for the total of the studied } \\
\text { population. For the three indicators (weight/age, size/age and weight/size) girls } \\
\text { who have a migrant father present a greater malnutrition incidence than the } \\
\text { children who are in the same situation. On the contrary, when the father does } \\
\text { not emigrate, girls have less incidence than boys. }\end{array}$ & Mexico \\
\hline $\begin{array}{l}\text { Jayatissa and } \\
\text { Wickramage (42) }\end{array}$ & $\begin{array}{l}\text { There is a lower incidence of growth retardation, loss of weight and low weight } \\
\text { among children of migrant households in comparison to children of non- } \\
\text { migrant houscholds. }\end{array}$ & Sri Lanka \\
\hline Ullmann (15) & $\begin{array}{l}\text { Wives of migrants are more likely to be overweight and be obese than wives of } \\
\text { non-migrants. }\end{array}$ & Mexico \\
\hline Wickramage et al. (6) & $\begin{array}{l}38.2 \% \text { of children from households with migrants had normal weight, in } \\
\text { comparison to } 46.9 \% \text { of households without migrants. } 30 \% \text { of children left } \\
\text { behind had low weight or very low weight, in comparison to } 17.7 \% \text { of non- } \\
\text { migrant children. However, these effects were not statistically significant } \\
(\mathrm{p}=0.061) \text {. }\end{array}$ & Sri Lanka \\
\hline Davis and Brazil (65) & $\begin{array}{l}\text { Migration of parents is associated with a } 0.427 \text { decrease in size-for-age, } \\
\text { indicating a greater level of growth retardation. }\end{array}$ & Guatemala \\
\hline
\end{tabular}

Souce: own work, based on reviewed literature 
Table 2. Main effects of emigration or return of a family member on health outcomes in the countries of origin (Continuation)

\begin{tabular}{|c|c|c|}
\hline Author & Effect on health & Country \\
\hline \multicolumn{3}{|c|}{ Nutrition and anthropometric measures } \\
\hline Hamilton and Choi (11) & $\begin{array}{l}\text { Out-migration is associated with an average decrease in birth weight, whereas } \\
\text { remittances and return migration are associated with an average increase in birth } \\
\text { weight. The sum of these opposite effects causes that migrating outside the } \\
\text { community raises birth weight, affecting the rates of low birth weight (LBW) } \\
\text { and macrosomia. }\end{array}$ & Mexico \\
\hline Carletto et al. (62) & $\begin{array}{l}\text { Children younger and older than } 30 \text { months, from migrant households, have } \\
\text { higher scores in size-for-age (HAZ), } 0.84 \text { more standard deviations. }\end{array}$ & Guatemala \\
\hline Sunil et al. (19) & $\begin{array}{l}\text { Infants in migrant households have lower percentages of LBW ( } 5.6 \%) \text { compared } \\
\text { with infants in non-migrant households ( } 6.3 \%) \text {. Migrant households show } \\
\text { approximately } 20 \% \text { lower odds of having LBW children. }\end{array}$ & Mexico \\
\hline Frank (17) & $\begin{array}{l}\text { Migration and remittances do not significantly affect the probability of having } \\
\text { LBW. }\end{array}$ & Mexico \\
\hline Gibson et al. (51) & $\begin{array}{l}\text { Having a migrant family member affects the diet of the household's members } \\
\text { that stay. In adults in working age, migration decreases the Body Mass Index } \\
\text { (BMI) in 10\% and the proportion between waist and hips in } 5 \% .\end{array}$ & Tonga \\
\hline Böhme et al. (18) & $\begin{array}{l}\text { Having a migrant child increases the BMI of older people approximately in } 5 \\
\text { points, which equals to a weight increase of } 14 \mathrm{~kg} \text { of an individual of } 1.70 \text { meters. }\end{array}$ & Moldavia \\
\hline $\mathrm{Lu}(39)$ & $\begin{array}{l}\text { In Mexico, children of international migrant parents have a lower height growth } \\
\text { than internal migrants or that live with their parents. Similar results are found in } \\
\text { Indonesia. }\end{array}$ & $\begin{array}{l}\text { Mexico } \\
\text { and } \\
\text { Indonesia }\end{array}$ \\
\hline $\begin{array}{l}\text { Hildebrandt and } \\
\text { McKenzic (3) }\end{array}$ & $\begin{array}{l}\text { There is a significant increase of birth weight, associated with having a migrant } \\
\text { in the houschold. }\end{array}$ & Mexico \\
\hline \multicolumn{3}{|c|}{ Health-related risk factors or protective factors for health } \\
\hline $\begin{array}{l}\text { Jayatissa and } \\
\text { Wickramage (42) }\end{array}$ & Childcare practices decrease when the father is a migrant worker. & Sri Lanka \\
\hline Hernández et_al (22) & $\begin{array}{l}\text { Pregnancy and raising are seen as control resources of wives, who are forced to } \\
\text { have unprotected sex when their husbands return. This favors the risk of } \\
\text { VIH/STD infections. }\end{array}$ & Mexico \\
\hline Palos-Lucio et al. (50) & $\begin{array}{l}\text { There is a negative association between physical activity of children and the time } \\
\text { passed since the family member emigrated to The USA. }\end{array}$ & Mexico \\
\hline Borges et al. (44) & $\begin{array}{l}\text { The incidence of alcohol, marihuana and cocaine consumption, at least once in a } \\
\text { lifetime, was greater among family members with migrants that among non- } \\
\text { migrant members. }\end{array}$ & Mexico \\
\hline Ming-Hsuan (13) & $\begin{array}{l}\text { Compared to children without migrant parents, the probability of smoking is } \\
\text { significantly lower than for children with a migrant parent, but greater for } \\
\text { children with both migrant parents. }\end{array}$ & China \\
\hline Gibson et al. (51) & $\begin{array}{l}\text { Adults in working age from families with emigrant members do not change the } \\
\text { habit of smoking, but they significantly consume more alcoholic beverages in a } \\
\text { monthly basis. This results becomes less significant when controls are added. }\end{array}$ & Tonga \\
\hline Böhme et al. (18) & $\begin{array}{l}\text { There is a positive effect of migration in older peoples' mobility (carry out more } \\
\text { activities in a daily basis). }\end{array}$ & Moldavia \\
\hline
\end{tabular}

Souce: own work, based on reviewed literature 
International Migration and Health in the Countries of Origin. The Effect on Households with Migrants and/or Recipients of Remittances, and on Returned Migrants. A Systematic Review

Table 2. Main effects of emigration or return of a family member on health outcomes in the countries of origin (Continuation)

\begin{tabular}{lll}
\hline Author & Effect on health & Country \\
\hline Child mortality & \multicolumn{1}{l}{$\begin{array}{l}\text { Children who are born in households with a migrant relative have less } \\
\text { probabilities of dying during their first year than those who are born in } \\
\text { McKenzie (3) }\end{array}$} & Mexico \\
\hline Yabiku et al. (67) & $\begin{array}{l}\text { No association between being the child of a migrant worker and child } \\
\text { mortality was found. }\end{array}$ & Mozambique \\
\hline Chauvet et al. (7) & $\begin{array}{l}\text { A 1\% increase of the expatriation rate of doctors increases the rates of child } \\
\text { mortality in approximately 0.35\%. }\end{array}$ & $\begin{array}{l}\text { Developing } \\
\text { countries }\end{array}$ \\
\hline Flores et al. (49) & $\begin{array}{l}\text { An increase of 10\% in the percentage of households with returnees is } \\
\text { associated with a decrease in the rates of child mortality of 5.5\%. }\end{array}$ & Mexico \\
\hline Banerjee et al. (40) & $\begin{array}{l}\text { Families with migrants have an advantage in relation to the households } \\
\text { without migrants regarding neonatal and postnatal child mortality caused by } \\
\text { low socio-economic conditions. }\end{array}$ & India \\
\hline Revista & $\begin{array}{l}\text { Babies who are born to women with recent migrating experience to The USA } \\
\text { have 40\% less probability of mortality during the first year of life, compared } \\
\text { to those of women without any migrating experience. Babies who are born in } \\
\text { households with one or more recent emigrants to The USA, have 7\% more } \\
\text { probability of child mortality than those born in households with zero recent } \\
\text { emigrants to The USA. }\end{array}$ & Mexico \\
\hline
\end{tabular}

Souce: own work, based on reviewed literature 
Table 2. Main effects of emigration or return of a family member on health outcomes in the countries of origin (Continuation)

\begin{tabular}{|c|c|c|}
\hline Author & Effect on health & Country \\
\hline \multicolumn{3}{|l|}{ General health condition } \\
\hline Schmeer (43) & $\begin{array}{l}\text { The probability that a child suffers from any disease is } 39 \% \text { higher when parents } \\
\text { are absent than when they are not. Children have } 51 \% \text { higher probability of } \\
\text { going through a diarrhea episode when parents are absent than when they are } \\
\text { not. }\end{array}$ & Mexico \\
\hline Carletto et al. (62) & $\begin{array}{l}\text { There is not a clear pattern and apparently, there is also a small difference } \\
\text { between migrants and non-migrants in the incidence of respiratory infections on } \\
\text { the child. Children from emigrant families have lower levels of diarrhea } \\
\text { compared to those of families without migrants. }\end{array}$ & Guatemala \\
\hline Ullmann (15) & $\begin{array}{l}\text { Wives of migrants are more likely to present heart diseases than non-migrant } \\
\text { wives are. }\end{array}$ & Mexico \\
\hline Smeekens et al. (14) & $\begin{array}{l}\text { Having a migrant parent has a negative effect in physical health of adolescents, in } \\
\text { comparison to adolescents who live with both parents. An adolescent with an } \\
\text { absent mother tends to have worse physical health compared to one who has an } \\
\text { "absent father". }\end{array}$ & Philippines \\
\hline $\begin{array}{l}\text { Carling and Tonnessen } \\
\text { (9) }\end{array}$ & $\begin{array}{l}\text { Paternal absence has an incidence on weight-for-height, diarrhea and cough in } \\
\text { children younger than } 5 \text { years. }\end{array}$ & Malawi \\
\hline $\begin{array}{l}\text { Donato and Duncan } \\
(68)\end{array}$ & $\begin{array}{l}\text { Children from households with migrants have a greater probability of having } \\
\text { good health in comparison to those of households without migrants. Children } \\
\text { from households with returnees experience significantly worse health } \\
\text { conditions. }\end{array}$ & Mexico \\
\hline Gibson et al. (51) & $\begin{array}{l}\text { The perception of health conditions of adults in working age does not change } \\
\text { with the migration of other members of the household. Older adults are less } \\
\text { likely to see themselves in a very good health condition when other family } \\
\text { members have migrated. There is not a significant impact on the BMI, waist hip } \\
\text { ratio, blood pressure or mental health. }\end{array}$ & Tonga \\
\hline Antman (45) & $\begin{array}{l}\text { Having a migrant child in The USA is associated with an increase of } 3.6 \\
\text { percentage points in the probability that older parents report poor health and to } \\
\text { an increase of } 1.1 \text { percentage points in the probability that they have poor } \\
\text { physical health. Women are more likely to report poor health. }\end{array}$ & Mexico \\
\hline Böhme et al. (18) & $\begin{array}{l}\text { Elderly people with migrant children appreciate more (a better category: in a } \\
\text { scale of five points) their health than elderly people without migrant children. } \\
\text { The cognitive capacity is not negatively affected by the migration of a biological } \\
\text { child. }\end{array}$ & Moldavia \\
\hline \multicolumn{3}{|l|}{ Pregnancy of adolescents } \\
\hline Battaglia (52) & $\begin{array}{l}\text { Having at least one household member living in The USA, decreases pregnancy } \\
\text { incidence among adolescents around } 0.339 \text { probability points. }\end{array}$ & Mexico \\
\hline \multicolumn{3}{|l|}{ Health expenditure } \\
\hline Cárdenas et al. (35) & $\begin{array}{l}\text { The migratory experience has a positive effect in the total monthly expenditure } \\
\text { on health of almost } \$ 29000 \text { (US } \$ 10 \text { aprox.), which in mainly boosted by the } \\
\text { effect in the households with returning migrants. The migrating impact in the } \\
\text { per capita health expenditure is } \$ 7000 \text { (US } \$ 2.3 \text { aprox.) }\end{array}$ & Colombia \\
\hline
\end{tabular}

Souce: own work, based on reviewed literature 


\section{Effect of transfers on health conditions of the household in the origin countries}

Family, financial and political connections are established among the countries of origin and destination, beyond their borders. Not only the emigrant modifies his cultural elements and those related to his identity, but he also helps reproducing the socio-cultural system of the place of origin. With migration, the cultural horizons of the communities of origin and destination broaden; lifestyles, ideas about family and the way to consume and behave also change. This exchange of knowledge and ways of living comprises the set of non-monetary transfers that complement remittances and produce effects on different aspects; including the health of the households in the countries of origin.

International migration can be considered as a determining factor in health of the countries of origin, due to its capacity to alter socio-economic and psichosocial circumstances of individuals and families. The migration effect on health is caused in part, by means of monetary transfers (remittances), or non-monetary transfers (cultural practices, norms and social arrangements)(17). It is clear that remittances can decrease during economic crisis, which affects health outcomes of the receiving families (number of visits to the hospital to take care of medical emergencies or amount of money destined to buy medications) (69). Remittances and repatriated savings alter the levels of income and wealth and the contact with health practices used in the countries of destination, increases knowledge about health and makes the use of financial resources more efficient (3).

According to Wilkerson et al. (16), migration of spouses can negatively affect mental health of women when they are forced to perform a different gender role than the one they are traditionally used to. On the contrary, according to Azzarri and Zezza (10), the impact on nutrition can be positive, considering remittances and the possibility than women can handle the budget, which increases the intake of kilocalories in the household and the growth patterns of children improve.

Remittances relieve income restrictions of households, enabling the purchase of medication, nutritional food and health services, which increases life expectation and decreases the child mortality rate (34). The effect on the percentage of health expenditure is also positive, especially for the households without an employment insurance (70,71). Likewise, Salinas (24) found that returning elder migrants could access to private health services and medications, due to remittances. On the contrary, Valero and Trevino (72) found that families with less resources can be far from starting to spend on health, in spite of the fact that their income increases marginally (remittances), since they consider that health is a need they can postpone in order to attend more important or imperative matters. 
Table 3 relates the main impacts that, may produce transfers, of cash or ideas, on health outcomes in the countries of origin. In general, results tend to be positive regarding the access to and use of health services, nutrition, fertility, mortality, life expectancy at birth, health expenditure and general health condition.

Regarding the access to or use of health services, it can be highlighted that receiving remittances affects positively the use of antiparastitic (60) and diabetes (24) medication, the use of outpatient and non-outpatient health services by children (38) and the substitution of public health services for private ones (31). On the other hand, patients who report the decrease of remittances are less likely to visit a hospital and take less prescribed medication (69).

In regards to nutrition, receiving remittances is associated with improvements in the nutritional condition of children younger than 5 years $(12,32,73)$. There is as well an asociation between receiving remittances and the decrease of fertility rates $(27,34,74)$ and child mortality $(7,12,34,49)$. Regarding the general health condition, receiving remittances decreases the probability of suffering from a chronic or sudden disease (36) and improves health outcomes, including the children's $(7,8,75)$.

In reference to health expenditure, receiving remittances increases medication expenditure $(29,76)$, hospitalization (29), medical visits and laboratoy services (36), preventive health activities (33) and, in general, the total health expenditure of households $(8,28,33,35,70,72,77,78,79,80,81)$.

On the other hand, regarding anthropometric measures, results are ambiguous. Some authors find that households that receive remittances present better anthropometric measures $(11,32,75)$, while others find negative results about these indicators $(19,37)$. Similar results are found in terms of risk factors or protectors. Some studies find a positive association between remittances and doing exercise (37) and others find negative effects (50).

Some studies did not find evidence that remittances affected health outcomes such as the proportion of children who attend school with malnutrition (73), consumption of health services (35), access to public health services (31), health expenditure of households (12), child mortality $(65,67)$ and that measure the long-term health condition of children (growth retardation, low weight), the prevalence of respiratory diseases and of diarrhea (33). 
International Migration and Health in the Countries of Origin. The Effect on Households with Migrants and/or Recipients of Remittances, and on Returned Migrants. A Systematic Review

Table 3. Main effects of cash transfers and of ideas on health outcomes in the countries of origin

\begin{tabular}{|c|c|c|}
\hline Author & Effect on health & Country \\
\hline \multicolumn{3}{|c|}{ Access to and use of health services } \\
\hline $\begin{array}{l}\text { López-Cevallos and } \\
\text { Chi }(60)\end{array}$ & $\begin{array}{l}\text { Remittances destined to health significantly increased the use of anti-parasitic } \\
\text { medication among low-income Ecuadorians, located in the rural area. }\end{array}$ & Ecuador \\
\hline Salinas (24) & $\begin{array}{l}\text { Receiving remittances or the return of resources from abroad allows the } \\
\text { payment of the diabetes treatment. If migrants cannot send remittances, } \\
\text { parents have problems handling diabetes. }\end{array}$ & Mexico \\
\hline $\begin{array}{l}\text { Nguyen and Nguyen } \\
(38)\end{array}$ & $\begin{array}{l}\text { Remittances increase the number of contacts of outpatient medical care in 14\% } \\
\text { and are strongly correlated to the contacts of medical care for hospitalized } \\
\text { patients. }\end{array}$ & Viernam \\
\hline Piette et al. (69) & $\begin{array}{l}\text { Patients with three or more chronic health problems had } 1.7 \text { more probability } \\
\text { of reporting remittances, in comparison to the patients who reported less } \\
\text { health conditions. }\end{array}$ & Honduras \\
\hline Ponce et al. (33) & $\begin{array}{l}\text { Increasing the amount of remittances in US\$10, increases the probability of } \\
\text { being vaccinated in } 5 \% \text { and removing parasites in } 6 \% \text {. }\end{array}$ & Ecuador \\
\hline Drabo and Ebeke (31) & $\begin{array}{l}\text { The elasticity of access to private health services, regarding remittances, is } \\
\text { positive and statistically significant. }\end{array}$ & $\begin{array}{l}\text { Developing } \\
\text { countries }\end{array}$ \\
\hline \multicolumn{3}{|c|}{ Nutrition and anthropometric measures } \\
\hline $\begin{array}{l}\text { Hamilton and Choi } \\
\text { (11) }\end{array}$ & $\begin{array}{l}\text { Each standard deviation increase in the percent of households in a community } \\
\text { receiving remittances increases mean birthweight by } 133.9 \mathrm{~g} \text {. }\end{array}$ & Mexico \\
\hline Sunil et al. (19) & $\begin{array}{l}\text { Contrary to expectations, migrant households that do not receive remittances } \\
\text { have } 29 \% \text { less probability of having low-weight births. There are no significant } \\
\text { results for households that receive remittances. }\end{array}$ & Mexico \\
\hline $\begin{array}{l}\text { Bebczuk and Battistón } \\
(80)\end{array}$ & $\begin{array}{l}\text { In Honduras, remittances have a positive and significant effect on Height-for- } \\
\text { age (size } \mathrm{z} \text { ) and Weight-for-age (weight } \mathrm{z} \text { ). In Ecuador, the effect is also positive } \\
\text { but the significance is at the limit. }\end{array}$ & $\begin{array}{l}\text { Ecuador, } \\
\text { Honduras, } \\
\text { Mexico, } \\
\text { Nicaragua }\end{array}$ \\
\hline $\begin{array}{l}\text { Castillo-Hernández et } \\
\text { al. (73) }\end{array}$ & $\begin{array}{l}\text { There is a positive association between receiving remittances and the absence } \\
\text { of short duration malnutrition in children younger than } 5 \text { years. The risk of } \\
\text { malnutrition in women of } 12-49 \text { years old who do not receive remittances is } \\
153 \text { times higher than in women who receive remittances. The risk of } \\
\text { malnutrition in children from } 5 \text { to } 11 \text { who do not receive remittances is lower } \\
\text { than in the families who receive remittances. }\end{array}$ & Mexico \\
\hline Acosta et al. (75) & $\begin{array}{l}\text { Controlling for income before migration, children from houscholds who } \\
\text { receive remittances tend to present better health outcomes (Weight-for-age } \\
\text { and Height-for-age) than those who do not receive remittances, with similar } \\
\text { demographic and socio-economic characteristics. }\end{array}$ & $\begin{array}{l}\text { Latin } \\
\text { American } \\
\text { countries }\end{array}$ \\
\hline Terrelonge (12) & $\begin{array}{l}\text { Increasing remittances in US\$100 decreases malnutrition measures, height-for- } \\
\text { age and height-for-age in } 5.4 \% \text { and } 7.7 \% \text {, respectively. Additional income due } \\
\text { to remittances of US } \$ 100 \text {, decrease the intensity of hunger in } 20 \text { kilokalories. }\end{array}$ & $\begin{array}{l}\text { Developing } \\
\text { countries }\end{array}$ \\
\hline Böhme et al. (18) & $\begin{array}{l}\text { The most frequent use that older people give to remittances is food. The } \\
\text { income effect of migration improves significantly the diets of older people. }\end{array}$ & Moldova \\
\hline $\begin{array}{l}\text { Anderson and Kroeger } \\
(37)\end{array}$ & $\begin{array}{l}\text { Children from households who receive remittances, who live in the South of } \\
\text { the country, on average, weight } 700 \text { grams less and are } 1.85 \mathrm{~cm} \text { smaller than } \\
\text { children of households who do not receive remittances. Receiving remittances } \\
\text { increases the probability that girls are thin in } 0.05 \text { and that are gravely thin in } \\
0.03 \text {. }\end{array}$ & Kyrgyzstan \\
\hline Antón (32) & $\begin{array}{l}\text { Remittances have a positive effect on the nutritional conditions of children on } \\
\text { the short and medium terms (WHZ and WAZ), but do not significantly affect } \\
\text { indicators on the long-term (HAZ), with the exception of children with highly } \\
\text { educated mothers }\end{array}$ & Ecuador \\
\hline
\end{tabular}

Source: own work, based on reviewed literature 
Table 3. Main effects of cash transfers and of ideas on health outcomes in the countries of origin (Continuation)

\begin{tabular}{|c|c|c|}
\hline Author & Effect on health & Country \\
\hline \multicolumn{3}{|l|}{ Health expenditure } \\
\hline $\begin{array}{l}\text { Díaz-González and } \\
\text { Ramírez-García }(81)\end{array}$ & $\begin{array}{l}\text { Remittances increase the probability that households spend more in health and } \\
\text { therefore, have a greater probability of incurring in a catastrophic expenditure. }\end{array}$ & Mexico \\
\hline Valero-Gil (70) & $\begin{array}{l}\text { Remittances positively affect the portion of the family's health expenditure, } \\
\text { but this effect is significantly lower for the households with an employment } \\
\text { medical insurance. }\end{array}$ & Mexico \\
\hline Mayer and $\mathrm{Le}(79)$ & $\begin{array}{l}\text { Households that receive remittances use a greater part of each additional peso } \\
\text { in food and health, mainly for the children. }\end{array}$ & Mexico \\
\hline Cárdenas et al. (35) & $\begin{array}{l}\text { Remittances have a positive effect on the total monthly expenditure on health } \\
\text { of almost } 49,000 \text { pesos and on monthly expenditure on health per capita of } \\
\text { approximately } \$ 11,000 \text {. }\end{array}$ & Colombia \\
\hline Ponce et al. (33) & $\begin{array}{l}\text { Increasing the amount of remittances in US } \$ 10 \text { increases health expenditure in } \\
5 \% \text {. }\end{array}$ & Ecuador \\
\hline Kalaj (36) & $\begin{array}{l}\text { Remittances affect positively and significantly the total expenditure on } \\
\text { medication of rural households, as well as the expenditure in medical visits and } \\
\text { laboratory services. }\end{array}$ & Albany \\
\hline Frank et al. (71) & $\begin{array}{l}\text { Remittances allow that people without formal access to a health insurance } \\
\text { program, based on the employer, can have medical care. }\end{array}$ & Mexico \\
\hline \multicolumn{3}{|l|}{ Health expenditure } \\
\hline $\begin{array}{l}\text { Adams and Cuecuecha } \\
(78)\end{array}$ & $\begin{array}{l}\text { Households spend } 3.27 \% \text { more of their income in health when they receive } \\
\text { remittances, in relation to those that do not receive them. }\end{array}$ & Ghana \\
\hline $\begin{array}{l}\text { Olowa and Awoyemi } \\
(77)\end{array}$ & $\begin{array}{l}\text { Households that receive remittances from abroad, spend } 12.81 \% \text { more in } \\
\text { health than those that do not receive them. }\end{array}$ & Nigeria \\
\hline Valero and Trivino $(72)$ & $\begin{array}{l}\text { If the households' income increase due to remittances, the total expenditure on } \\
\text { health of the households with access to a labor medical insurance (ASSML) } \\
\text { increases in } 0.9 \% \text { and without ASSML in } 6.6 \% \text {. }\end{array}$ & Mexico \\
\hline $\begin{array}{l}\text { González-Block et al. } \\
(76)\end{array}$ & $\begin{array}{l}\text { People who depend on migrants who: presented a health problem in the last } \\
\text { year, took home-made remedies in order to solve their problem, bought } \\
\text { medication and attended a private supplier, reported, using remittances to pay } \\
\text { for health care more frequently. }\end{array}$ & Mexico \\
\hline $\begin{array}{l}\text { Amuedo-Dorantes and } \\
\text { Pozo (28) }\end{array}$ & $\begin{array}{l}\text { An increase of } 100 \text { pesos in remittance income, increases health expenditure } \\
\text { between } 5 \text { and } 6 \text { pesos. }\end{array}$ & Mexico \\
\hline $\begin{array}{l}\text { Bebczuk and Battistón } \\
(80)\end{array}$ & $\begin{array}{l}\text { Total remittances seem to boost health expenditure in all the countries, except } \\
\text { for Honduras. Per capita remittances have a significant effect on health } \\
\text { expenditure in the three countries. }\end{array}$ & $\begin{array}{l}\text { Ecuador, } \\
\text { Honduras, } \\
\text { Mexico, } \\
\text { Nicaragua }\end{array}$ \\
\hline $\begin{array}{l}\text { Amuedo-Dorantes et al. } \\
\text { (29) }\end{array}$ & $\begin{array}{l}\text { Each additional peso in remittances raises the households' expenditure in: } \\
\text { primary care from } 6 \text { to } 9 \text { dollar cents (with the exception of rural households), } \\
\text { hospitalization from } 12 \text { to } 20 \text { dollar cents (except for the female-headed } \\
\text { households) and un-prescribed medication from } 2 \text { to } 4 \text { dollar cents. }\end{array}$ & Mexico \\
\hline
\end{tabular}

Source: own work, based on reviewed literature 
International Migration and Health in the Countries of Origin. The Effect on Households with Migrants and/or Recipients of Remittances, and on Returned Migrants. A Systematic Review

Table 3. Main effects of cash transfers and of ideas on health outcomes in the countries of origin (Continuation)

\begin{tabular}{|c|c|c|}
\hline Author & Effect on health & Country \\
\hline \multicolumn{3}{|l|}{ Child mortality } \\
\hline Flores et al. (49) & $\begin{array}{l}\text { An increase of } 10 \% \text { in the percentage of households that receive remittances } \\
\text { decreases the child mortality rates in } 1.4 \% \text {. }\end{array}$ & Mexico \\
\hline Chauvet et al. (7) & $\begin{array}{l}\text { The estimated impact of remittances on child and infant mortality rates is } \\
\text { between } 0.09 \text { and }-0.10 \text { for children in the fourth quintile and between }-0.11 \\
\text { and }-0.13 \text { for children in the fifth quintile. }\end{array}$ & $\begin{array}{l}\text { Developing } \\
\text { countries }\end{array}$ \\
\hline Hamilton et al. (48) & $\begin{array}{l}\text { Receiving remittances by mothers, decreases the probability of infant mortality } \\
\text { in } 7 \% \text {. In the rural area, children of women who receive a significant amount of } \\
\text { remittances, have } 20 \% \text { less probability of dying in their first year of life. }\end{array}$ & Mexico \\
\hline Zhunio et al. (34) & $\begin{array}{l}\text { An increase of } 1 \% \text { in real per capita remittances, results in a decrease of } 0.15 \% \\
\text { in infant mortality. }\end{array}$ & $\begin{array}{l}\text { Developing } \\
\text { countries }\end{array}$ \\
\hline Terrelonge (12) & $\begin{array}{l}\text { A hundred additional dollars of income due to per capita remittances produces } \\
\text { a decrease of } 7.8 \text { children deaths every } 1000 \text { born alive, and a decrease of } 5.7 \text { of } \\
\text { infant deaths every } 1000 \text { born alive. An increase of } 1 \% \text { in per capita } \\
\text { remittances decreases child and infant mortality in approximately } 0.10 \% \text { and } \\
0.11 \% \text {, respectively. Based on elasticity estimations, an increase of } 102.3 \% \text { in } \\
\text { per capita remittances between } 1995 \text { and } 2009 \text { was found, which can be } \\
\text { translated to a decrease of } 10.6 \% \text { in child mortality and a decrease of } 11.3 \% \text { in } \\
\text { infant mortality. }\end{array}$ & $\begin{array}{l}\text { Developing } \\
\text { countries }\end{array}$ \\
\hline \multicolumn{3}{|c|}{ Health-related risk factors or protective factors for health } \\
\hline $\begin{array}{l}\text { Anderson and Krocger } \\
\text { (37) }\end{array}$ & $\begin{array}{l}\text { International remittances have a positive effect in doing exercise in children } \\
\text { between } 7 \text { and } 18 \text { years old of the South of Kyrgyzstan. }\end{array}$ & Kyrgyzstan \\
\hline \multicolumn{3}{|l|}{ Mental health } \\
\hline Graham et al. (26) & $\begin{array}{l}\text { The probability that caregivers who receive remittances had suffered from } \\
\text { CMD (Common Mental Disorders) in the last six months, was } 30 \% \text { less than } \\
\text { for those who did not receive remittances. }\end{array}$ & $\begin{array}{l}\text { Indonesia, } \\
\text { Phillipines } \\
\text { and Vietnam }\end{array}$ \\
\hline Siriwardhana et al. (23) & $\begin{array}{l}\text { The decrease in the frequency of sending remittances is associated with greater } \\
\text { levels of CMD among spouses of migrant workers. This is not observed in } \\
\text { caregivers that are not spouses. }\end{array}$ & Sri Lanka \\
\hline \multicolumn{3}{|c|}{ ( } \\
\hline Beine et al. (27) & $\begin{array}{l}\text { A decrease of } 1 \% \text { in the norms of fertility to which emigrants are exposed to, } \\
\text { decreases fertility in around } 0.3 \% \text { in their country of origin. }\end{array}$ & $\begin{array}{l}\text { Developing } \\
\text { countries }\end{array}$ \\
\hline $\begin{array}{l}\text { Naufal and Vargas-Silva } \\
(74)\end{array}$ & $\begin{array}{l}\text { There is a negative relation between remittances and fertility rates. Emigrants } \\
\text { also transfer ideas to their families in their country of origin, emphasizing their } \\
\text { efforts to achieve the purpose of lower fertility. }\end{array}$ & $\begin{array}{l}\text { Developing } \\
\text { countries }\end{array}$ \\
\hline Zhunio et al. (34) & $\begin{array}{l}\text { An increase of } 1 \% \text { in per capita remittances, leads to a } 0.09 \% \text { decrease in the } \\
\text { fertility rate. }\end{array}$ & $\begin{array}{l}\text { Developing } \\
\text { countries }\end{array}$ \\
\hline \multicolumn{3}{|l|}{ Birth Expectancy at Birth } \\
\hline Zhunio et al. (34) & $\begin{array}{l}\text { An increase of } 1 \% \text { in real per capita remittances, results in a } 0.03 \% \text { increase in } \\
\text { life expectancy. }\end{array}$ & $\begin{array}{l}\text { Developing } \\
\text { countries }\end{array}$ \\
\hline $\begin{array}{l}\text { Amakon and Iheoma } \\
\text { (8) }\end{array}$ & $\begin{array}{l}\text { Life expectancy at birth increases } 1.2 \% \text { on average after an increase of } 10 \% \text { in } \\
\text { remittances. }\end{array}$ & $\begin{array}{l}\text { Sub-Saharan } \\
\text { Africa }\end{array}$ \\
\hline
\end{tabular}

Source: own work, based on reviewed literature 


\section{Effects of migratory experience on the health condition of those who returned}

Health outcomes in the countries of origin can be affected by the return of nationals, since, when returning, they can be older, sick, disabled or having suffered a deportation, which would place them in vulnerable position. However, it is also possible that who return have the economic means to attend their needs regarding health services.

According to Wong and González-González (82), migrants can return to the country of origin being older adults and suffering from some degree of disability or poverty, when they have been subdued to intense physical work in the countries of destination. For Bojorquez et al. (83), this result can be worse in the case of forced returnees, among which greater predominance of common mental problems can be present. In fact, Habtamu et al. (84) found that Ethiopian migrants who returned from the Middle East and South Africa, experienced symptoms of common mental disorders (headaches, lack of appetite, fatigue, insomnia and feeling of unhappiness or nervousness). This psychological distress and even long-term mental illnesses could be related to adversities experienced by immigrants in the different migratory stages (not receiving their salary on time, not having contact with their families, lack of awareness on the type of work they must carry out and lack of necessary knowledge and abilities for the work, etc.).

For Fernández-Niño et al. (85), deported ones are more likely to perceive their own health as poor or very poor, which is an expression of the accumulation of vulnerabilities to which they have been exposed to, considering their undocumented condition. Barrett and Mosca (46) found that returned women had less problems with alcohol, inasmuch as, the benefits of the migratory experience (sense of independence and control) exceeded the costs (nostalgia). On the contrary, returned men had a greater dependence on alcohol, due to the stress caused by migration.

Cabre et al. (86) studied the probability that migration had an influence on the risk of developing multiple sclerosis in the French Antilles. They found that the appearance of this disease had a more environmental origin rather than a genetic one and could be due to the fact that migrants would have introduced the factors that precipitated it or to that in the Antilles, the environmental factors that protected the population from this disease would have disappeared.

Finally, the greater predominance of smoking and obesity among returned Mexicans after living in The United States can be by cause of their greater economic capacity to buy cigarettes, food and high calorie drinks. Their emotional and psychiatric disorders can be the result of anti-migrant legislation and hostile political climate that Mexican immigrants deal with in The United States (20). 
Table 4 shows that the migratory experience may produce positive or negative effects on mental health of migrants who return to their country of origin. The other health indicators analyzed in the studies are negatively affected. For instance, results in the French Antilles, show that the prevalance of multiple sclerosis was higher among those who returned than in those who had not migrated (86). In other cases, the migratory experience was positively associated with the presence of heart desease and obesity among those who returned (20) and with greater disability in older adults (82). Those who were deported were more likely to perceive poor health conditions (85), and have more risk factors, such as alcohol consumption (46) and smoking (20).

Regarding mental health, women report having the feeling of independence and control as a pyschic benefit, which prevails over psychic costs like nostalgia (46). Other authors found unfavorable results on mental health. For instance, Miyasaka et al. (87) could establish that migrants who returned from Japan to Brazil were mainly single men with a psychiatric history, to which schizophrenia was diagnosed, associated with the loneliness that they had experienced during their stay abroad. Ullmann et al. (20) positively related the migratory experience of returnees to Mexico to emotional or psychiatric disorders. Regarding the deported returnees, Fernández-Niño et al. (85) found them more likely to report negative emotional symptoms and Bojorquez et al. (83) associated a longer stay at The United States with a greater presence of common mental disorders (CMD) in Mexico. Similar results were found in Ethiopia in (84).

Finally, some authors did not find that the migratory experience affected certain health outcomes in the country of origin. For instance, Ullmann et al. (20) did not find an association between the migratory experience and the report of good health in adults and Borges et al. (66) did not find any differences in regards to suicidal risk among individuals without a personal mirgration history or migrant family members, and returned migrants. 
Table 4. Main effects of the migratory experience on the health condition of the returnees

\begin{tabular}{|c|c|c|}
\hline Author & Effect on health & Country \\
\hline \multicolumn{3}{|l|}{ General health condition } \\
\hline $\begin{array}{l}\text { Wong and Gonzalez-Gonzalez. } \\
\text { (82) }\end{array}$ & $\begin{array}{l}\text { On average, returning migrants lost the original physical advantage they had before migration, compared to } \\
\text { those who stayed in Mexico. }\end{array}$ & Mexico \\
\hline Cabre et al. (86) & $\begin{array}{l}\text { The incidence of multiple sclerosis among people from } 15 \text { to } 64 \text { years old was } 36.1 / 100000 \text { for migrants and } \\
15,1 / 100000 \text { for non-migrants. There was also a relation between the length of overseas stay and the appearance } \\
\text { of the disease. The average of time between the arrival to France and the development of multiple sclerosis was } \\
19.1 \text { years, which can correspond to the incubation period of the disease. }\end{array}$ & $\begin{array}{l}\text { Guadeloupe } \\
\text { and } \\
\text { Martinique }\end{array}$ \\
\hline Femández-Nińo et al. (85) & $\begin{array}{l}\text { The deported migrants are more likely to perceive their health as poor or very poor, in comparison to migrants } \\
\text { who returned voluntarily }\end{array}$ & Mexico \\
\hline \multicolumn{3}{|l|}{ Mental health } \\
\hline Bojorquez et al. (83) & $\begin{array}{l}\text { For migrant deported, a } U \text { relation between the time in which the person lived in The United States and the } \\
\text { SRQ score that measures CMD was observed. }\end{array}$ & Mexico \\
\hline Miyasaka et al. (87) & Most of the single men returnees from Japan to Brazil were diagnosed with schizophreni2 & Brazil \\
\hline Habtamu et al. (8i) & $\begin{array}{l}\text { The CMD incidence among Ethiopian returnees, proceeding from the Middle East and South Africa (27.6\%) is } \\
\text { superior to the incidence of the general population (between } 5 \% \text { y } 22 \% \text { ). }\end{array}$ & Ethiopia \\
\hline Fernández-Niño et al. (85) & $\begin{array}{l}\text { Los deported migrants are more likely to report negative emotional symptoms, in comparison to migrants who } \\
\text { returned voluntarily. }\end{array}$ & Mexico \\
\hline Barrett and Mosca (46) & $\begin{array}{l}\text { Migration produces psychic benefits in Irish women who lived abroad, such as independence and control, which } \\
\text { prevail over the psychic costs that are usually associated with migration, such as nostalgia. }\end{array}$ & Ireland \\
\hline \multicolumn{3}{|c|}{ Health-related risk factors or protective factors for health } \\
\hline Barrett and Mosea (46) & $\begin{array}{l}\text { Returnees have a greater probability of have had problems with alcohol at some moment, compared to non- } \\
\text { migrants. This is also true for women who had lived abroad for } 10 \text { or less years. Women who had lived abroad } \\
\text { for } 10 \text { or more years had a lower probability of suffering from alcoholism. }\end{array}$ & Ireland \\
\hline Ullmann et al. (20) & $\begin{array}{l}\text { The migratory experience of Mexicans, who return from The USA, is positively and significantly associated with } \\
\text { obesity and having smoked once. Therefore, returning migrants reported worse health than non-migrants. }\end{array}$ & Mexico \\
\hline
\end{tabular}

Source: own work, based on reviewed literature

\section{Conclusions}

The objective of this work is to carry out a literature review aimed at answering the following research question: which are the effects of international migration - seen as remittances, return or emigration - on the households' health results or on people in the contries of origin.

The review of articles was carried out systematically, by means of an exhasutive and rigurous analysis of several data bases, according to previously established eligibility cirteria. Likewise, data extracted from every document was recorded in a table of evidence and the review methodology was clearly presented; through which any person can reproduce it.

Considering that the objective was providing a global view of the stage of the research in the topic, among the criteria for selecting articles, the methdological aspects were not taken into account, in order not to exclude those that contribute with the problem's understanding. Indeed, great methodological heterogeneity among the articles reviewed was found. This impeded contrasting populations, sample sizes and types of studies in the way demanded by a systematic literature review to reach to strong conclusions that this type of review assures. 
As expected, en general terms, results are not consistent. For the same health indicator, the effect of international migration may differ among countries and considering different groups of population, considering gender, ethnic group and age. This may also be due to the complexity of international migration and health depending on multiple factors. The migratory phenomenon in the countries of origin, apart from obbeying to multiple causes, comprises remittances, return and emigration. Health outcomes are due to genetic, environmental, socioeconomic factors and life styles, some of which may be influenced by the migratory experience of the family member who emigrated or returned.

According to the documents reviewed, the fact that a family member of the household had emigrated or returned has different effects on health. It positively affects the general health condition, the anthropometric measures, nutrition and child mortality and, negatively, mental health and risk factors. With regard to access to health services, most studies reported positive effects.

In general terms, cash or non-cash transfers, have a positive influence on health of the countries of origin. On the other hand, many of the authors that studied the health condition of the returnees found that the migratory experience affected health in a negative way .

Several reasons can affect health as a consequence of international migration. Remittances, specifically, strengthen the household's finances and decrease the need of child labor, producing an increase in the access to health services and expenditure in this area. Separation of parents and children can decrease the support and supervision provided to children, fostering the acquisition of harmful habits and harboring feelings of anger and sadness. This can also decrease the influence of pregnancy among adolescents.

Migrants and those who returned may transfer predominant behavioral rules in their countries of destination and contribute to modify ideas and cultural practices that have an influence on health, in the same way that migration of the spouse can modify the gender roles within the households and increase the responsibility of women, causing their mental health to be affected.

This review will be highly useful for those who study the subject. It will enable the advance in the research to be determined, the exisitng voids, the new questions that may arise, the most appropriate methodologies to answer them, as well as the less studied countries and populations. It would be interesting to establish, for instance, until what point, results on the health of the countries of origin when it is the mother who migrates, differ. 
Therefore, in view of the considerable dimension that international migration has assumed, and the importance of health in terms of human development, there is a need for more studies to be put forward. These studies could take into consideration the construction of compound indicators that integrate several health outcomes, given that international migration can simultaneaoulsy affect different aspects of health. Also, qualitative research that enables the analysis of quantitative results in wider social and cultural contexts must be encouraged, as well as accessing people's lives, their daily routines and their social relationships.

\section{References}

1. World Bank. Migration: Overview [Internet]. 2016 [access 2016 Nov. 22]. Available at: https://www .worldbank.org/en/topic/migrationremittancesdiasporaissues/overview

2. World Health Organization. Health and the Millennium Development Goals [Internet]. 2005 [access 2016 Jan. 12]. Available at: http://www.who.int/hdp/publications/mdg_en.pdf

3. Hildebrandt N, McKenzie DJ. The Effects of Migration on Child Health in Mexico. Economía. $2005 ; 6(1): 257-289$.

4. Aguilera-Guzmán RM, Salgado-de-Snyder VN, Romero M, Medina-Mora ME. Paternal absence and international migration: stressors and compensators associated with the mental health of mexican teenagers of rural origin. Adolescence. 2004;39(156):711-723.

5. Pottinger AM. Children's experience of loss by parental migration in inner-city Jamaica. Am J Orthopsychiatry. 2005;75(4):485-496.

6. Wickramage K, Siriwardhana C, Vidanapathirana P, Weerawarna S, Jayasekara B, Pannala G, et al. Risk of mental health and nutritional problems for left-behind children of international labor migrants. BMC Psychiatry. 2015;15(39):1-12.

7. Chauvet L, Gubert F, Mesple-Somps S. Aid, Remittances, Medical Brain Drain and Child Mortality: Evidence Using Inter and Intra-Country Data. J Dev Stud. 2013;49(6):801-818.

8. Amakom U, Iheoma CG. Impact of Migrant Remittances on Health and Education Outcomes in SubSaharan Africa. IOSR-IJHSS. 2014;9(8):33-44.

9. Carling J, Tønnessen M. Fathers' whereabouts and children's welfare in Malawi. Dev. South. Afr. 2013;30(6):724-742.

10. Azzarri C, Zezza A. International migration and nutritional outcomes in Tajikistan. Food Policy. 2011;36(1):54-70.

11. Hamilton ER, Choi KH. The mixed effects of migration: Community-level migration and birthweight in Mexico. Soc Sci Med. 2015;(132):278-286.

12. Terrelonge SC. For Health, Strength and Daily Food: The Dual Impact of Remittances and Public Health Expenditure on Household Health Spending and Child Health Outcomes. J Dev Stud. 2014;50(10):1397-1410. 
International Migration and Health in the Countries of Origin. The Effect on Households with Migrants and/or Recipients of Remittances, and on Returned Migrants. A Systematic Review

13. Ming-Hsuan L. Migration and Children's Welfare in China: The Schooling and Health of Children Left behind. J Develop Area. 2011;44(2):165-182.

14. Smeekens C, Stroebe MS, Abakoumkin G. The impact of migratory separation from parents on the health of adolescents in the Philippines. Soc Sci Med. 2012;75(12): 2250-2257.

15. Ullmann SH. The health impacts of international migration on Mexican women. Glob. Public Health. 2012;7(9):946-960.

16. Wilkerson JA, Yamawaki N, Downs SD. Effects of husbands' migration on mental health and gender role ideology of rural Mexican women. Health Care Women Int. 2009;30(7):614-628.

17. Frank R. International Migration and Infant Health in Mexico. J. Immigr. Health. 2005;7(1):11-22.

18. Böhme MH, Persian R, Stöhr T. Alone but better off? Adult child migration and health of elderly parents in Moldova. J Health Econ. 2015;39:211-227.

19. Sunil TS, Flores M, Garcia GE. New evidence on the effects of international migration on the risk of low birthweight in Mexico. Matern Child Nutr. 2012;8(2):185-198.

20. Ullmann SH, Goldman N, Massey DS. Healthier before they migrate, less healthy when they return? The health of returned migrants in Mexico. Soc Sci Med. 2011;73(3):421-428.

21. Caballero M, Leyva-Flores R, Ochoa-Marín SC, Zarco Á, Guerrero C. Las mujeres que se quedan: Migración e implicación en los procesos de búsqueda de atención de servicios de salud. Salud Pública Méx. 2008;50(3):241-250.

22. Hernández-Rosete D, Maya García O, Bernal E, Castañeda X, Lemp G. Migración y ruralización del SIDA: relatos de vulnerabilidad en comunidades indígenas de México. Rev. Saúde Pública. 2008;42(1):131-138.

23. Siriwardhana C, Wickramage K, Jayaweera K, Adikari A, Weerawarna S, Van-Bortel T, et al. Impact of Economic Labour Migration: A Qualitative Exploration of Left-Behind Family Member Perspectives in Sri Lanka. J Immigr Minor Health. 2015;17(3):885-894.

24. Salinas JJ. Tapping Healthcare Resource by Older Mexicans with Diabetes: How Migration to the United States Facilitates Access. J Cross Cult Gerontol. 2008;23(3):301-312.

25. Rivera-Heredia ME, Obregón-Velasco N, Cervantes-Pacheco EI. Migración, sucesos estresantes y salud: perspectivas de las mujeres michoacanas de comunidades rurales con familiares migrantes. Acta Univ. 2013;23(1):49-59.

26. Graham E, Jordan LP, Yeoh BS. A. Parental migration and the mental health of those who stay behind to care for children in South-East Asia. Soc Sci Med. 2015;132:225-235.

27. Beine M, Docquier F, Schiff M. International Migration, Transfers of Norms and Home Country Fertility [Working Paper]. Geneva: The World Bank, Development Research Group, Trade Team; $2009 ; 44925$.

28. Amuedo-Dorantes C, Pozo S. New Evidence on the Role of Remittances on Health Care Expenditures by Mexican Households [Discussion Paper]. Bonn, Germany: IZA; 2009; 4617.

29. Amuedo-Dorantes C, Sainz T, Pozo S. Remittances and Healthcare Expenditure Patterns of Populations in Origin Communities: Evidence from Mexico [Working paper]. Buenos Aires, 
Argentina: Inter-American Development Bank, Integration and Regional Programs Department; $2007 ; 25$.

30. Medina C, Cardona L. The Effects of Remittances on Household Consumption, Education Attendance and Living Standards: the Case of Colombia. Lect Econ. 2010;(72):11-43.

31. Drabo A, Ebeke C. Remittances. Public Health Spending and Foreign Aid in the Access to Health Care Services in Developing Countries [Working paper]. Clermont Ferrand, France: Cerdi; 2010.

32. Antón JI. The Impact of Remittances on Nutritional Status of Children in Ecuador. International Migration Review. 2010;44(2):269-299.

33. Ponce J, Olivié I, Onofa M. The role of international remittances in health outcomes in Ecuador: Prevention and response to shocks. Int Migr Rev. 2011;45(3):727-745.

34. Zhunio MC, Vishwasrao S, Chiang EP. The influence of remittances on education and health outcomes: a cross country study. App. Econ. 2012;44(35):4605-4616.

35. Cárdenas M, Medina C, Trejos A. Measuring Economic and Social Impacts of Migration in Colombia: New evidence [Working paper]. Bogotá, Colombia: Banco de la República; 2010; 601.

36. Kalaj EH. A Micro-level Analysis of the Effect of Remittances on Health Expenditures: Evidence from Albania. Mediterr J Soc Sci. 2015;6(1):665-673.

37. Anderson K, Kroeger A. Remittances and Children`s Capabilities: New Evidence from Kyrgyzstan, 2005-2008 [Discussion paper]. Bonn, Germany: Forschungsinstitut zur Zukunft der Arbeit; 2012; 6293.

38. Nguyen C, Nguyen H. Do Internal and International Remittances Matter to Health, Education and Labor of Children? The Case of Vietnam [Working paper]. Munich, Germany: Personal RePec Archive, MPRA; 2013; 48672.

39. Lu Y. Internal migration, international migration, and physical growth of left-behind children: A study of two settings. Health Place. 2015;36:118-126. https://www.doi.org/10.1016/j.healthplace.20 15.09.008

40. Banerjee SK, Jayachandran V, Roy TK. Has Emigration Influenced Kerala's Living Standards? A Micro Level Investigation. Econ Polit Wkly. 2002;37(18):1755-1765.

41. Lindstrom DP, Muñoz-Franco E. Migration and the diffusion of modern contraceptive knowledge and use in rural Guatemala. Studies in Family Planning. 2005;36(4):277-288.

42. Jayatissa R, Wickramage K. What Effect Does International Migration Have on the Nutritional Status and Child Care Practices of Children Left Behind? Int. J. Environ. Res. Public Health. 2016;13(218):1-10.

43. Schmeer K. Father absence due to migration and child illness in rural Mexico. Soc Sci Med. 2009;69(8):1281-1286. 
International Migration and Health in the Countries of Origin. The Effect on Households with Migrants and/or Recipients of Remittances, and on Returned Migrants. A Systematic Review

44. Borges G, Medina-Mora ME, Breslau J, Aguilar-Gaxiola S. The effect of migration to the United States on substance use disorders among returned Mexican migrants and families of migrants. Am J Public Health. 2007;97(10):1847-1851.

45. Antman FM. Adult Child Migration and the Health of Elderly Parents Left Behind in Mexico. Am. Econ. Rev. 2010;100(2):205-208.

46. Barrett A, Mosca I. The psychic costs of migration: Evidence from Irish return migrants. J. Popul. Econ. 2013;26(2):483-506.

47. Siriwardhana C, Wickramage K, Siribaddana S, Vidanapathirana P, Jayasekara B, Weerawarna S, et al. Common mental disorders among adult members of "left-behind" international migrant worker families in Sri Lanka. BMC Public Health. 2015;(15):1-9.

48. Hamilton ER, Villarreal A, Hummer RA. Mother's, household, and community U.S. migration experience and infant mortality in rural and urban Mexico. Popul. Res. Policy Rev. 2009;28(2):123-142.

49. Flores M, Sunil T, Picazzo-Palencia E, Cortez-Hernandez DE. A Spatial Analysis of the Effects of International Migration on Infant Mortality in Mexico. Soc Dev Issues. 2012;34(2):1-15.

50. Palos-Lucio G, Flores M, Rivera-Pasquel M, Salgado-de-Snyder VN, Monterrubio E, Henao S, et al. Association between migration and physical activity of school-age children left behind in rural Mexico. Int J Med. Public Health. 2015;60(1):49-58. https://www.doi.org/10.1007/s00038-014-063 $0-2$

51. Gibson J, McKenzie D, Stillman S. The Impacts of International Migration on Remaining Household Members Omnibus Results from a Migration Lottery Program [Working paper]. Washington, DC: The World Bank Development Research Group, Trade and Integration Team; 2009; 4956.

52. Battaglia M. Migration, health knowledge and teenage fertility: Evidence from Mexico. SERIEs. 2015;6(2):179-206.

53. Adhikari R, Jampaklay A, Chamratrithirong A, Richter K, Pattaravanich U, Vapattanawong P. The Impact of Parental Migration on the Mental Health of Children Left Behind. J. Immigr. Minor. Health. 2014;16(5):781-789. https://www.doi.org/10.1007/s10903-013-9809-5

54. Vanore M, Mazzucato V, Siegel M. "Left behind" but not left alone: Parental migration \& the psychosocial health of children in Moldova. Soc Sci Med. 2015;132:252-260.

55. Mazzucato V, Cebotari V, Veale A, White A, Grassi M, Vivet J. International parental migration and the psychological well-being of children in Ghana, Nigeria, and Angola. Soc Sci Med. 2015;132:215-224.

56. Mosca I, Barrett A. The Impact of Adult Child Emigration on the Mental Health of Older Parents [Discussion paper]. Bonn, Germany: The Institute for the Study of Labor (IZA); 2014; 8037.

57. Nobles J, Rubalcava L, Teruel G. After spouses depart: Emotional wellbeing among nonmigrant Mexican mothers. Soc Sci Med. 2015;132:236-244.

58. Bojorquez I, Salgado-de-Snyder N, Casique I. International migration of partner, autonomy and depressive symptoms among women from a mexican rural area. Int. J. Soc. Psychiatry. 2009;55(4):306-321. 
59. Salgado-De-Snyder VN, González-Vázquez T, Infante-Xibille C, Márquez-Serrano M, PelcastreVillafuerte B, Serván-Mori EE. Servicios de salud en la Mixteca: Utilización y condición de afiliación en hogares de migrantes y no-migrantes a EU. Salud Pública Méx. 2010;52(5):424-431.

60. López-Cevallos DF, Chi C. Health Care Utilization in Ecuador. Rev Panam Salud Públ. 2012;31(1):9-16.

61. Lindstrom DP, Muñoz-Franco E. Migration and maternal health services utilization in rural Guatemala. Soc Sci Med. 2006;63(3):706-721.

62. Carletto C, Covarrubias K, Maluccio JA. Migration and child growth in rural Guatemala. Food Policy. 2011;36(1):16-27.

63. Gibson J, McKenzie D, Stillman S. What happens to diet and child health when migration splits households? Evidence from a migration lottery program. Food Policy. 2011;36(1):7-15.

64. Acosta LD, Vizcarra-Bordi I. Desnutrición infantil en comunidades mazahuas con migración masculina internacional en México Central. Poblac. Salud Mesoam. 2009;6(2):118.

65. Davis J, Brazil N. Migration, Remittances and Nutrition Outcomes of Left-Behind Children: A National-Level Quantitative Assessment of Guatemala. PLOS ONE. 2016;11(3):1-17.

66. Borges G, Breslau J, Su M, Miller M, Medina-Mora ME, Aguilar-Gaxiola S. Immigration and suicidal behavior among Mexicans and Mexican Americans. Am J Public Health. 2009;99(4):728-733.

67. Yabiku ST, Agadjanian V, Cau B. Labor migration and child mortality in Mozambique. Soc Sci Med. 2012;75(12):2530-2538.

68. Donato KM, Duncan EM. Migration, Social Networks, and Child Health in Mexican Families. J. Marriage Fam.. 2011;73(4):713-728.

69. Piette JD, Mendoza-Avelares MO, Chess L, Milton EC, Reyes AM, Rodriguez-saldaña J. Report on Honduras: ripples in the pond-the financial crisis and remittances to chronically ill patients in Honduras. Int. J. Health Serv. 2012;42(2):197-212.

70. Valero-Gil J. Remittances and the Household's Expenditures on Health. J Bus Strat. 2009;26(1):119-140.

71. Frank R, Palma-Coca O, Rauda-Esquivel J, Olaiz-Fernández G, Díaz-Olavarrieta C, Acevedo-García D. The relationship between remittances and health care provision in Mexico. Am. J. Public Health. 2009;99(7):1227-1231.

72. Valero JN, Trevino MDL. El gasto en salud de los hogares en México, y su relación con la disponibilidad de recursos, las remesas y la asignación intrafamiliar. Econo. Mex. (Nueva Época). 2010;19(2):311-342.

73. Castillo Hernández JL, Álvarez Ramírez MM, Romero Hernández EY, Cortés SC, Zenteno-Cuevas R, Berrún-Castañón LN. Asociación de las remesas con el estado nutricio y la adecuación de la dieta en habitantes de la localidad El Espinal, municipio de Naolinco, Veracruz, México. Rev. Avanc. Seg. Alim. y Nutr. 2009;1(1):77-87. 
74. Naufal G, Vargas-Silva C. Changing Fertility Preferences One Migrant at a Time: The Impact of Remittances on the Fertility Rate [Discussion paper]. Bonn, Germany: The Institute for the Study of Labor (IZA); 2009; 4066.

75. Acosta P, Fajnzylber P, Lopez H. The Impact of Remittances on Poverty and Human Capital: Evidence from Latin American Household Surveys [Working paper]. Washington, DC: The World Bank; 2007; 4247.

76. González-Block MÁ, De-la-Sierra-de-la-Vega LA, Vargas-Bustamante A. Utilización de remesas de migrantes en California para atención a la salud de sus dependientes en México. Salud Pública Méx. 2013;55(4):459-468.

77. Olowa OW, Awoyemi TT. Remittances and Household Expenditure in Rural Nigeria. J Rural Econ Dev. 2009;20(1):30-43.

78. Adams RH, Cuecuecha A. The Impact of Remittances on Investment and Poverty in Ghana. World Dev. 2013;50:24-40.

79. Mayer D, Le Thi ML. El uso de las transferencias privadas inter-vivos por los hogares: el caso de México. Estud Demogr Urb. 2008;23(2):233-269.

80. Bebczuk R, Battistón D. Remittances and Life Cycle Deficits in Latin America [Working paper]. La Plata, Argentina: Universidad Nacional de la Plata; 2010; 94.

81. Díaz-González E, Ramírez-García JB. Gastos catastróficos en salud, transferencias gubernamentales y remesas en México. Pap Pobl. 2017;23(91):65-91.

82. Wong R, Gonzalez-Gonzalez C. Old-Age Disability and Wealth Among Return Mexican Migrants From the United States. J. Aging Health. 2010;22(7):932-354.

83. Bojorquez I, Aguilera RM, Ramírez J, Cerecero D, Mejía S. Common Mental Disorders at the Time of Deportation: A Survey at the Mexico-United States Border. J. Immigr. Health. 2015;17(6):1732-1738.

84. Habtamu K, Minaye A, Zeleke WA. Prevalence and associated factors of common mental disorders among Ethiopian migrant returnees from the Middle East and South Africa. BMC Psychiatry. 2017;17(1):1-12.

85. Fernández-Niño JA, Ramírez-Valdés DJ, Cerecero-Garcia D, Bojorquez-Chapela I. Deported Mexican migrants: Health status and access to care. Rev. Saúde Pública. 2014;48(3):478-485.

86. Cabre P, Signate A, Olindo S, Merle H, Caparros-Lefebvre D, Béra O, Smadja D. Role of return migration in the emergence of multiple sclerosis in the French West Indies. Brain. 2005;128(12): 2899-2910.

87. Miyasaka SL, Canasiro S, Abe Y, Otsuka K, Tsuji K, Hayashi T, et al. Migration and mental health: Japanese Brazilians in Japan and in Brazil. J. Bras. Psiquiatr. 2007;56(1):48-52. 


\section{Annex}

Annex 1. Type of study, target population and sample size of the works reviewed

\begin{tabular}{|c|c|c|c|}
\hline Author & Type of study & Target population & Sample size \\
\hline Ming-Hstuan (13) & $\begin{array}{l}\text { Cross-sectional study- } \\
\text { comparative }\end{array}$ & $\begin{array}{l}\text { Children (defined as individuals berween } 6 \text { and } 18 \text { years of age) } \\
\text { - Sex of the child is not specified }\end{array}$ & 913 \\
\hline $\begin{array}{l}\text { Lindstrom and Mutioz- } \\
\text { Franco }(41)\end{array}$ & Cross-sectional study & $\begin{array}{l}\text { Women between the ages of } 18 \text { and } 35 \text { with a family member } \\
\text { of a migrant }\end{array}$ & 2531 \\
\hline $\begin{array}{l}\text { Lindstrom and Muñoz- } \\
\text { Franco }(61)\end{array}$ & Cross-sectional study & Pregnant women between the ages of 18 and 35 & $\begin{array}{l}1838 \text { whose last pregnancy ended } \\
\text { in a live birth }\end{array}$ \\
\hline Schmeer (43) & Longitudinal-comparative & Children between 0 to 5 years & 46,870 \\
\hline Battaglia (52) & Longitudinal & Women between the ages of 15 and 54 & 39,133 \\
\hline $\begin{array}{l}\text { Donato and Duncan } \\
(68)\end{array}$ & Longitudinal-comparative & Children under 10 years old & 804 \\
\hline Frank (17) & Cross-sectional study & Newly born & 565 \\
\hline $\begin{array}{l}\text { Hildebrandt and } \\
\text { McKenzie (3) }\end{array}$ & Cross-sectional study & Children & 12,117 \\
\hline Gibson et al. (51) & Longitudinal-comparative & Houschold's family members who stay & $\begin{array}{l}\text { stayer household } N=118 ; \text { stayer } \\
\text { children } N=146 ; \text { stayer } \\
\text { working-age adults } N=176 ; \\
\text { stayer older adults } N=121\end{array}$ \\
\hline Antman (45) & Longitudinal-comparative & Elderly parents & 6730 \\
\hline Smeekens et al. (14) & Longitudinal-comparative & Adolescents between the ages of 13 and 18 & 205 \\
\hline Ullmann (15) & $\begin{array}{l}\text { Cross-sectional study- } \\
\text { comparative }\end{array}$ & Wives & 1850 \\
\hline $\begin{array}{l}\text { Carling and Tonnessen } \\
\text { (9) }\end{array}$ & $\begin{array}{l}\text { Cross-sectional study- } \\
\text { comparative }\end{array}$ & Children under 15 years old & 46,626 \\
\hline $\begin{array}{l}\text { Rivera-Heredia et al. } \\
\text { (25) }\end{array}$ & $\begin{array}{l}\text { Cross-sectional study- } \\
\text { narrative research design }\end{array}$ & Women with a migrant family & 62 \\
\hline $\begin{array}{l}\text { Aguilera-Guzmán et al. } \\
\text { (4) }\end{array}$ & $\begin{array}{l}\text { Cross-sectional study - } \\
\text { ethnographic mixed-method } \\
\text { design }\end{array}$ & Adolescents with a migrant father & $\begin{array}{l}\text { quantitative methods } N=310 \\
\text { and qualitative methods } N=24\end{array}$ \\
\hline Pottinger (5) & $\begin{array}{l}\text { Cross-sectional study-cases } \\
\text { and controls }\end{array}$ & Children between 9 to 10 years & 54 \\
\hline Wilkerson et al. (16) & Cross-sectional study & Women from 18 to 50 years old with a migrant husband & 94 \\
\hline Adhikari et al. (53) & Cross-sectional study & Children & 1030 \\
\hline Mosca and Barrett (56) & $\begin{array}{l}\text { Cross-sectional study- } \\
\text { comparative }\end{array}$ & Pcople aged 50 and above living in Ireland & 2911 \\
\hline Graham et al. (26) & $\begin{array}{l}\text { Cross-sectional study- } \\
\text { comparative -ethnographic } \\
\text { mixed-method design }\end{array}$ & $\begin{array}{l}\text { Carers (three groups of carers within transnational households, } \\
\text { differentiated by their gender and relationship to the index } \\
\text { child (mother-carer/father-migrant; father-carer/ mother- } \\
\text { migrant; other-carer/parent(s)-migrant)) }\end{array}$ & $\begin{array}{l}\text { Indonesia }(n=1025) \\
\text { Philippines }(n=990) \text { and } \\
\text { Vietnam }(n=1011)\end{array}$ \\
\hline Mazzucato et al. (55) & $\begin{array}{l}\text { Cross-sectional study- } \\
\text { comparative }\end{array}$ & Children and youths aged 11.21 & $\begin{array}{l}\text { Ghana } n=2760 ; \text { Angola } n= \\
2243 ; \text { Nigeria } n=2168\end{array}$ \\
\hline Nobles et al. (57) & Longitudinal-comparative & $\begin{array}{l}\text { Partnered mothers who in } 2002 \text { had co resident minors } \\
\text { (children under } 18 \text { years old) and who were themselves aged } \\
18-44 \text {, aged during which spousal migration to the U.S. is } \\
\text { concentrated. }\end{array}$ & 2813 \\
\hline
\end{tabular}

Source: own work, based on reviewed literature 
International Migration and Health in the Countries of Origin. The Effect on Households with Migrants and/or Recipients of Remittances, and on Returned Migrants. A Systematic Review

\section{Annex 1.Type of study, target population and sample size of the works reviewed (Continuation)}

\begin{tabular}{|c|c|c|c|}
\hline Author & Type of study & Target population & Sample size \\
\hline Siriwardhana et al. (47) & $\begin{array}{l}\text { Cross-sectional study- } \\
\text { comparative }\end{array}$ & $\begin{array}{l}\text { Spouse and a non-spouse caregiver (defined for the study } \\
\text { purposes as a person living in the migrant family household, } \\
\text { not a parent of the child/children in the family but responsible } \\
\text { for providing a significant amount of care for them on a daily } \\
\text { basis) }\end{array}$ & 465 \\
\hline Wickramage et al. (6) & $\begin{array}{l}\text { Cross-sectional study- } \\
\text { comparative }\end{array}$ & Children between 12 to 17 years & 820 \\
\hline Caballero et al. (21) & $\begin{array}{l}\text { ethnographic mixed-method } \\
\text { design }\end{array}$ & Female partners of migrants & 60 \\
\hline $\begin{array}{l}\text { Acosta and Vizcarra- } \\
\text { Bordi }(64)\end{array}$ & $\begin{array}{l}\text { Cross-sectional study - } \\
\text { descriptive }\end{array}$ & Children between one and five years & 534 \\
\hline Azzarri and Zezza (10) & Cross-sectional study & Children under five years & 2480 \\
\hline Gibson et al. (63) & Longitudinal-comparative & Children under 18 & 182 \\
\hline Hamilton et al. (48) & Cross-sectional study & $\begin{array}{l}\text { Women between the ages of } 15 \text { and } 49 \text { who are not missing } \\
\text { information on our key independent (i.e. migration) and } \\
\text { dependent (i.e. infant mortality) measures. }\end{array}$ & 896,148 \\
\hline Borges et al. (44) & $\begin{array}{l}\text { Cross-sectional study. } \\
\text { comparative }\end{array}$ & $\begin{array}{l}\text { Household residents aged } 18 \text { to } 65 \text { years who lived in Mexico } \\
\text { in cities with population of at least } 2500 \text { people in } 2001 \text { and } \\
2002 \text {. }\end{array}$ & 5826 \\
\hline Carletto et al. (62) & $\begin{array}{l}\text { Cross-sectional study. } \\
\text { comparative }\end{array}$ & $\begin{array}{l}\text { Children below } 6 \text { years of age with valid HAZ (Height for } \\
\text { Age) information, from } 658 \text { distinct households. }\end{array}$ & 1083 \\
\hline Banerjec et al. (40) & $\begin{array}{l}\text { Cross-sectional study- } \\
\text { comparative }\end{array}$ & Households & 4387 \\
\hline $\begin{array}{l}\text { Anderson and Krocger } \\
\text { (37) }\end{array}$ & Longitudinal-comparative & Children aged 6-18 & $\begin{array}{l}4995(6285) \text { households } \\
\text { (children aged 6-18) for } 2008 \text {, } \\
4803 \text { (6306) for } 2007,4863 \\
(6564) \text { for } 2006 \text { and } 4771(6449) \\
\text { for } 2005 \text {. }\end{array}$ \\
\hline $\begin{array}{l}\text { Nguyen and Nguyen } \\
\text { (38) }\end{array}$ & Longitudinal-comparative & Children aged 6-18 & 21,292 \\
\hline $\begin{array}{l}\text { Olowa and Awoyemi } \\
\text { (77) }\end{array}$ & $\begin{array}{l}\text { Cross-sectional study- } \\
\text { comparative }\end{array}$ & Rural houscholds & 14,512 \\
\hline $\begin{array}{l}\text { Adams and Cuecuecha } \\
\text { ( } 78 \text { ) }\end{array}$ & $\begin{array}{l}\text { Cross-sectional study- } \\
\text { comparative }\end{array}$ & Remittance receiving household & 3941 \\
\hline Beine et al. (27) & $\begin{array}{l}\text { Cross-sectional study- } \\
\text { comparative }\end{array}$ & Households from countries that receive remittances & 208 \\
\hline $\begin{array}{l}\text { Naufal and Vargas-Silva } \\
\text { (74) }\end{array}$ & Longitudinal-comparative & Remittances receiving countries & $\begin{array}{l}59 \text { countries with data for most } \\
\text { countries for the period } 1980 \text { to } \\
2005\end{array}$ \\
\hline Mayer and Le (79) & Longitudinal-comparative & Remittance receiving household & 6068 \\
\hline Valero and Trivino (72) & $\begin{array}{l}\text { Cross-sectional study- } \\
\text { comparative }\end{array}$ & Remittance receiving houschold & 22,595 \\
\hline
\end{tabular}

Source: own work, based on reviewed literature 
Luis Miguel Tovar-Cuevas / María Teresa Victoria-Paredes / Camilo Zarama / Matheo Arellano-Morales

Annex 1.Type of study, target population and sample size of the works reviewed (Continuation)

\begin{tabular}{|c|c|c|c|}
\hline Author & Type of study & Target population & Sample size \\
\hline $\begin{array}{l}\text { González-Block et al. } \\
(76)\end{array}$ & $\begin{array}{l}\text { Cross-sectional study- } \\
\text { comparative }\end{array}$ & $\begin{array}{l}\text { Men and women of } 18 \text { or older that comply with any of the } \\
\text { following criteria: a) born in Mexico and living in the US at the } \\
\text { moment of the survey, or b) being a United States citizen with } \\
\text { family members in Mexico and have used health services in } \\
\text { Mexico. }\end{array}$ & $\begin{array}{l}741 \text { observations of migrants } \\
\text { who reported having family } \\
\text { members in Mexico. }\end{array}$ \\
\hline $\begin{array}{l}\text { Amuedo-Dorantes et al. } \\
\text { (29) }\end{array}$ & Cross-sectional study & Remittance receiving household & 17,167 \\
\hline $\begin{array}{l}\text { Amuedo-Dorantes and } \\
\text { Pozo (28) }\end{array}$ & Cross-sectional study & Remittance receiving household & 16,074 \\
\hline Frank et al. (71) & $\begin{array}{l}\text { Cross-sectional study- } \\
\text { comparative }\end{array}$ & Remittance receiving household & 2044 \\
\hline Valero-Gil $(70)$ & $\begin{array}{l}\text { Cross-sectional study- } \\
\text { Comparative }\end{array}$ & Remittance receiving houschold & 22,595 \\
\hline Kalaj (36) & $\begin{array}{l}\text { Cross-sectional study- } \\
\text { comparative }\end{array}$ & Remittance receiving households members & 4641 \\
\hline Medina (30) & $\begin{array}{l}\text { Cross-sectional study- } \\
\text { comparative }\end{array}$ & Remittance receiving household & 2000 \\
\hline Terrelonge (12) & Longitudinal & Households from developing countries that receive remittances & $\begin{array}{l}138 \text { developing countries; } 1029 \\
\text { households }\end{array}$ \\
\hline Drabo and Ebeke (31) & $\begin{array}{l}\text { Cross-sectional study } \\
\text { comparative }\end{array}$ & Children from households with migrants & $\begin{array}{l}380 \text { childrens with fever and } 392 \\
\text { childrens with diarrhea }\end{array}$ \\
\hline $\begin{array}{l}\text { Castillo-Hernández et } \\
\text { al. (73) }\end{array}$ & $\begin{array}{l}\text { Cross-sectional study. } \\
\text { Descriptive }\end{array}$ & $\begin{array}{l}\text { Children under five, schoolchildren and women of } \\
\text { reproductive age from the El Espinal locality, municipality of } \\
\text { Naolinco, Veracruz. }\end{array}$ & $\begin{array}{l}\text { total }=1889 \text {; childrens under five } \\
=315 ; \text { schoolchildrens }=367 \\
\text { and women of reproductive age }= \\
1207\end{array}$ \\
\hline Antón (32) & $\begin{array}{l}\text { Cross-sectional study- } \\
\text { Comparative }\end{array}$ & $\begin{array}{l}\text { Children under five years from remittance receiving } \\
\text { households }\end{array}$ & 5798 \\
\hline Acosta ct al. (75) & $\begin{array}{l}\text { Cross-sectional study- } \\
\text { Comparative }\end{array}$ & Remittance receiving houscholds of each countries & \\
\hline $\begin{array}{l}\text { Bebczuk and Battistón } \\
(80)\end{array}$ & $\begin{array}{l}\text { Cross-sectional study- } \\
\text { Comparative }\end{array}$ & Remittance receiving houscholds & \\
\hline Ponce ct al. (33) & $\begin{array}{l}\text { Cross-sectional study- } \\
\text { Comparative }\end{array}$ & Remittance receiving houscholds & 55,666 \\
\hline Zhunio et al. (34) & Longitudinal & $\begin{array}{l}\text { Remittance receiving houscholds of low-and middle-income } \\
\text { countries. }\end{array}$ & 69 \\
\hline $\begin{array}{l}\text { Amakon and lheoma } \\
(8)\end{array}$ & Longitudinal & $\begin{array}{l}\text { Remittance receiving households of low-and middle-income } \\
\text { countries. }\end{array}$ & 18 \\
\hline Chauvet et al. (7) & Longitudinal & Child mortality in developing in remittance receiving countries & $\begin{array}{l}\text { The dataset covers } 46 \text { developing } \\
\text { countries among which } 26 \text { are in } \\
\text { Africa, with five asset quintiles } \\
\text { for each country-year, giving a } \\
\text { total of } 370 \text { country-time- } \\
\text { quintile observations. }\end{array}$ \\
\hline Miyasaka et al. (87) & $\begin{array}{l}\text { Cross-sectional study- } \\
\text { comparative }\end{array}$ & $\begin{array}{l}\text { Japanese Brazilian outpatients who received care from the } \\
\text { psychiatric units in Japan and Brazil from April } 1997 \text { to April } \\
2000\end{array}$ & $\begin{array}{l}\text { Brazil, } n=100 \text { and Japan, } n= \\
107\end{array}$ \\
\hline Cabre et al. (86) & $\begin{array}{l}\text { Cross-sectional study- } \\
\text { comparative }\end{array}$ & Individuals aged between 15 and 64 years & 1600 \\
\hline Ullmann et al. (20) & $\begin{array}{l}\text { Cross-sectional study. } \\
\text { comparative }\end{array}$ & $\begin{array}{l}\text { Male heads of household between the ages of } 19 \text { and } 102 \text { who } \\
\text { were interviewed between } 2007 \text { and } 2009\end{array}$ & 2121 \\
\hline Barrett and Mosca (46) & $\begin{array}{l}\text { Cross-sectional study- } \\
\text { comparative }\end{array}$ & $\begin{array}{l}\text { People aged } 50 \text { and over (and of their spouses or partners of } \\
\text { any age) resident in Ireland }\end{array}$ & Male $=2770$ and female $=3244$ \\
\hline
\end{tabular}

Source: own work, based on reviewed literature 
International Migration and Health in the Countries of Origin. The Effect on Households with Migrants and/or Recipients of Remittances, and on Returned Migrants. A Systematic Review

\section{Annex 1.Type of study, target population and sample size of the works reviewed (Continuation)}

\begin{tabular}{|c|c|c|c|}
\hline Author & Type of study & Target population & Sample size \\
\hline $\begin{array}{l}\text { Fernindez-Nino et al. } \\
\text { (85) }\end{array}$ & $\begin{array}{l}\text { Cross-sectional study. } \\
\text { comparative }\end{array}$ & Voluntary-return migrants and deported & $\begin{array}{l}2680 \text { voluntary-return migrants, } \\
\text { and } 6862 \text { deportees. }\end{array}$ \\
\hline Sunil et al. (19) & $\begin{array}{l}\text { Cross-sectional study- } \\
\text { comparative }\end{array}$ & $\begin{array}{l}\text { Children from Mexican households with a migrant family } \\
\text { member it the United States }\end{array}$ & $\begin{array}{l}\text { total sample: } 39949 \text { infants. } 2489 \\
\text { are reported to be LBW } \\
(<2500 \mathrm{~g}) \text { and } 36960 \text { are } \\
\text { reported to be normal weight } \\
(2500 \mathrm{~g})\end{array}$ \\
\hline $\begin{array}{l}\text { Hamilton and Choi } \\
\text { (11) }\end{array}$ & $\begin{array}{l}\text { Cross-sectional study- } \\
\text { comparative }\end{array}$ & Child health results at the community level & $3,675,489$ births \\
\hline Flores et al. (49) & $\begin{array}{l}\text { Cross-sectional study- } \\
\text { comparative }\end{array}$ & Mexican municipalities with high migration rates & 2443 \\
\hline $\begin{array}{l}\text { López-Cevallos and Chi } \\
(60)\end{array}$ & $\begin{array}{l}\text { Cross-sectional study- } \\
\text { comparative }\end{array}$ & $\begin{array}{l}\text { Households with an international migrant and remittance } \\
\text { receiving houscholds }\end{array}$ & 10,985 \\
\hline Cárdenas et al. (35) & $\begin{array}{l}\text { Cross-sectional study- } \\
\text { comparative }\end{array}$ & $\begin{array}{l}\text { Households with family members living abroad and returned } \\
\text { migrants }\end{array}$ & 269,060 \\
\hline $\begin{array}{l}\text { Salgado de Snyder et al. } \\
\text { (59) }\end{array}$ & $\begin{array}{l}\text { Descriptive cross-sectional } \\
\text { study descriptive }\end{array}$ & Household who have migrants and non-migrants & Heads of 702 houscholds. \\
\hline Vanore_ct_al (54) & $\begin{array}{l}\text { Comparative cross-sectional } \\
\text { study. }\end{array}$ & Children of migrant and non-migrant parents & 1979 children \\
\hline $\begin{array}{l}\text { Jayatissa and } \\
\text { Wickramage (42) }\end{array}$ & Cross-sectional study & Children of migrant parents & $\begin{array}{l}321 \text { children between } 6 \text { and } 59 \\
\text { months old }\end{array}$ \\
\hline Siriwardhana et al. (23) & $\begin{array}{l}\text { A critical realist perspective } \\
\text { was adopted in the design of } \\
\text { the qualitative study }\end{array}$ & Families with a migrant member & Heads of 20 households. \\
\hline Salinas (24) & Narrative study & $\begin{array}{l}\text { Older adults with diabetes, who were migrants or have a } \\
\text { migrant family member }\end{array}$ & $\begin{array}{l}37 \text { older adults between } 48 \text { and } \\
90 \text { years old. }\end{array}$ \\
\hline Piette et al. (69) & Cross-sectional study & Adults with a chronical disease who receive remittances & 624 \\
\hline $\begin{array}{l}\text { Diaz-Gonzalez and } \\
\text { Ramírez-García ( } 81 \text { ) }\end{array}$ & Cross-sectional study & $\begin{array}{l}\text { Households that spend on health, including those who receive } \\
\text { subsidies from the government and remittances from migrant } \\
\text { family members. }\end{array}$ & $\begin{array}{l}\text { NSIEH that includes } 29,074,332 \\
\text { households, 14,105,718 report } \\
\text { health-related expenditure }\end{array}$ \\
\hline Hernández et_al (22) & Echnographic Design & $\begin{array}{l}\text { Indigenous women cohabitating with men who practice } \\
\text { unprotected sex }\end{array}$ & $\begin{array}{l}91 \text { people: } 24 \text { temporary } \\
\text { migrants, } 33 \text { indigenous women, } \\
20 \text { local authorities and } 14 \\
\text { people from the health area }\end{array}$ \\
\hline $\begin{array}{l}\text { Wong and Gonzalez- } \\
\text { Gonzalez (82) }\end{array}$ & Cross-sectional study & $\begin{array}{l}\text { Older adults older than } 60 \text { years old, with international } \\
\text { migratory experience }\end{array}$ & 7141 \\
\hline Bojorquez et al. (83) & Cross-sectional study & Deported migrants older than 18 years old & 1619 \\
\hline Habtamu et al. (84) & Cross-sectional study & Returned migrants & 1036 \\
\hline Borges et al. (66) & Longitudinal & $\begin{array}{l}\text { Houscholds with a migrant family member, migrants and } \\
\text { having been born in the migration country, but are } \\
\text { migrants'children }\end{array}$ & $\begin{array}{l}2 \text { data panels: US }(2001-2003) N \\
=1284 . \text { Mexico }(2001-2002) N \\
=5782\end{array}$ \\
\hline Yabiku et al. (67) & Longitudinal & Children from labor migrants & 1932 children \\
\hline Davis and Brazil (65) & Cross-sectional study & Children from migrant parents & 244 children \\
\hline Palos-Lucio et al. (50) & Cross-sectional study & Children with a migrant family member & $\begin{array}{l}239 \text { children between } 9 \text { and } 12 \\
\text { years old }\end{array}$ \\
\hline Bōhme et al. (18) & Cross-sectional study & $\begin{array}{l}\text { Migrant and non-migrant households with members aged } 60 \\
\text { and older, whom was define as the elderly. }\end{array}$ & $\begin{array}{l}\text { The analytical sample comprises } \\
1566 \text { elderly from } 111 \text { localities } \\
\text { for which all relevant } \\
\text { information are available and } \\
\text { which have at least one child. }\end{array}$ \\
\hline $\operatorname{Lu}(39)$ & Longitudinal-comparative & $\begin{array}{l}\text { Children age } 0-12 \text { in Mexico and children age } 0-8 \text { in } \\
\text { Indonesia }\end{array}$ & $\begin{array}{l}\text { The number of panel children } \\
\text { include for final analysis in } \\
\text { Indonesia and Mexico was } 5246 \\
\text { and } 3484\end{array}$ \\
\hline Bojorquez et al. (58) & Cross-sectional study & Women in Mexico, whose husband is living abroad. & 418 \\
\hline
\end{tabular}

Source: own work, based on reviewed literature 
Luis Miguel Tovar-Cuevas / María Teresa Victoria-Paredes / Camilo Zarama / Matheo Arellano-Morales

\section{Notes}

* Research article 